\title{
Lithological control on the deformation mechanism and the mode of fault slip on the Longitudinal Valley Fault, Taiwan
}

\author{
Marion Y. Thomas ${ }^{\mathrm{a}}$, Jean-Philippe Avouac ${ }^{\mathrm{a}}$, Jean-Pierre Gratier ${ }^{\mathrm{b}, \mathrm{c}}$, \\ Jian-Cheng Lee ${ }^{\mathrm{d}}$ \\ ${ }^{a}$ Department of Geological and Planetary Sciences, California institute of Technology, \\ Pasadena, CA 91125, USA. \\ ${ }^{b}$ Univ. Grenoble Alpes, ISTerre, F-38041 Grenoble, France \\ ${ }^{c}$ CNRS, ISTerre, F-38041 Grenoble, France \\ ${ }^{d}$ Institute of Earth Sciences, Academia Sinica, Nankang, Taipei 115, Taiwan, ROC
}

\begin{abstract}
The Longitudinal Valley Fault (LVF) in Taiwan is creeping at shallow depth along its southern half, where it is bounded by the Lichi Mélange. By contrast, the northern segment of the LVF is locked where it is bounded by forearc sedimentary and volcanoclastic formations. Structural and petrographic investigations show that the Lichi Mélange most probably formed as a result of internal deformation of the forearc when the continental shelf of South China collided with the Luzon arc as a result of the subduction of the South China Sea beneath the Philippine Sea Plate. The forearc formations constitute the protolith of the Lichi Mélange. It seems improbable that the mechanical properties of the minerals of the matrix (illite, chorite, kaolinite) in themself explain the aseismic bevavior of the LVF. Microstructural investigations show that deformation within the fault zone must have resulted from a combination of frictional sliding at grain boundaries, cataclasis (responsible for grain size comminution) and pressure solution creep (responsible for the development of the scaly foliation and favored by the mixing of soluble and insoluble minerals). The microstructure of the gouge
\end{abstract}


formed in the Lichi Mélange favors effective pressure solution creep, which inhibits strain-weakening brittle mechanisms and is probably responsible for the dominantly aseismic mode of fault slip. Since the Lichi Mélange is analogous to any unlithified subduction mélanges, this study sheds light on the mechanisms which favor aseismic creep on subduction megathrust.

Keywords: Taiwan, Longitudinal Valley Fault, aseismic slip, deformation mechanism, Lichi Mélange, pressure solution creep, frictional sliding

\section{Introduction}

Geodetic and seismological observations show that fault slip can be either seismic or aseismic. The observation that locked fault patches tend to coincide with seismic ruptures, combined with numerical studies, suggests that the partitioning between aseismic and seimic slip is an influential and perhaps determining factor governing the spatial extent, size and timing of earthquake ruptures (e.g., Harris and Segall, 1987; Chlieh et al., 2008; Hsu et al., 2009a; Hashimoto et al., 2009; Kaneko et al., 2010; Noda and Lapusta, 2010; Moreno et al., 2010; Perfettini et al., 2010; Loveless and Meade, 2011; Barbot et al., 2012; Thomas et al., 2014b). However, the factors that determine the mode of fault slip, and hence the seismogenic potential of faults, are still poorly understood. Ascertaining those factors by defining the spatial and temporal variability of frictional properties, and understanding the deformation mechanisms and their relative importance are therefore major goals in seismotectonics.

We propose to address this problem by investigating the deformation mechanisms that control aseismic slip on the Longitudinal Valley Fault (LVF) in Taiwan. This fault runs parallel to the East coast of Taiwan and defines the plate boundary between the Chinese continental margin, considered to 


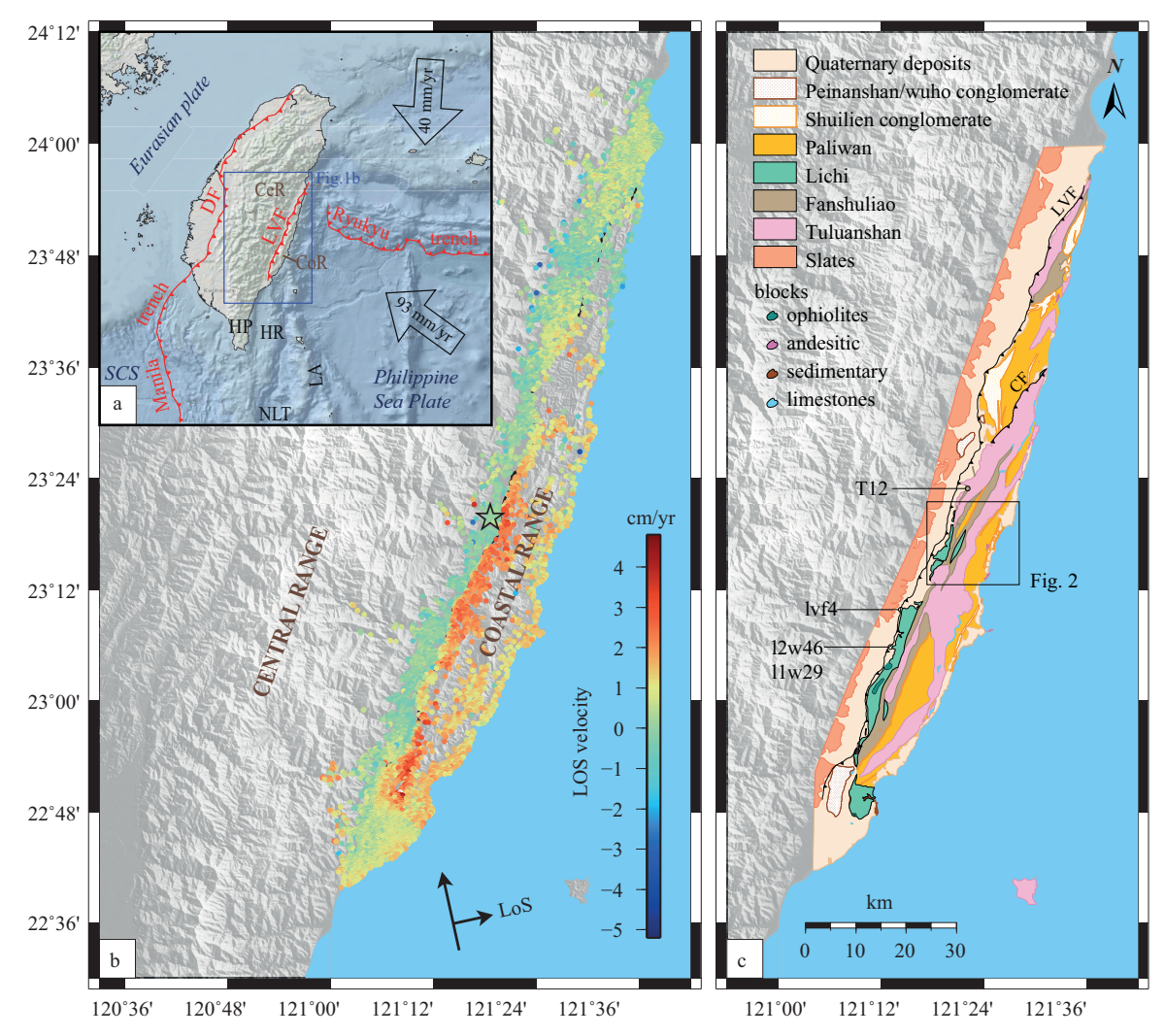

Figure 1: (a) Regional tectonic setting of the Longitudinal Valley Fault. (b) Mean line of sight (LOS) velocity (in $\mathrm{cm} / \mathrm{yr}$ ) around the Longitudinal Valley Fault derived from the Persistent Scatter (PS) technique applied to PALSAR ALOS data acquired between 1/29/2007 and 6/2/2010 (Champenois et al., 2012; Thomas et al., 2014a). Velocities are expressed relative to the mean velocity of a reference area, indicated by the black star. Black arrows show the ascending track direction and the LOS, which has an incidence of about $35^{\circ}$ on average (relative to the vertical). (c) Geological map of eastern Taiwan (modified from Wang and Chen (1993)). The Coastal Range is composed of three accreted Mio-Pliocene volcanic islands (Tuluanshan formation), three remnants of Plio-Plesitocene forearc basins and intra-arc basins (Fanhsuliao, Paliwan and Shuilien conglomerate), and the Pliocene collision Lichi Mélange, which is related to the suturing of the subduction zone due to the collision between the Luzon arc (see subfigure (a)) and the continental margin of South China (Chang et al., 2000, 2001, 2009; Huang et al., 2006a, 2008; Hirtzel et al., 2009). Peinanshan and the Wuho are post-collision conglomerates. Central Range formations that border the Longitudinal Valley, include slates and schist Wang and Chen (1993). DF-deformation front; CeRCentral Range; CF-Chimei Fault; CoR-Coastal Range; HG-Hengchun peninsula; HR-Huatung Ridge; LA-Luzon Arc; LVF-Longitudinal Valley Fault; NLT-North Luzon Trough; SCS-South China Sea. 
be part of the Eurasian plate, and the oceanic Philippine Sea Plate (Lee et al., 2001; Chang et al., 2009) (Fig. 1). This fault is known to creep near the surface (Angelier et al., 1997; Lee et al., 1998, 2000, 2001, 2003, 2005; Hsu and Burgmann, 2006; Lee et al., 2006; Chang et al., 2009; Cheng et al., 2009; Hsu et al., 2009b; Huang et al., 2010; Peyret et al., 2011; Champenois et al., 2012; Chen et al., 2012; Chuang et al., 2012; Thomas et al., 2014a) but has also produced large earthquakes, with $M_{w}>6.8$ events in 1938, 1951 and 2003 (Fig. S1 in supplements) (Wu et al., 2006; Shyu et al., 2007; Chung et al., 2008; Hsu et al., 2009a; Thomas et al., 2014a). Modeling of the spatio-temporal evolution of seismic and aseismic slip on the LVF, derived from the inversion of geodetic and seismological data, has demonstrated that as much as $80-90 \%$ of the $\sim 4.5 \mathrm{~cm} / \mathrm{yr}$ slip rate on the southern section of the LVF, in the 0-26 km seismogenic depth range (as defined by local seismicity), is actually the result of aseismic creep (Thomas et al., 2014a). The spatial pattern of aseismic creep on the LVF is very heterogeneous, showing both along dip and along strike variations. Creep is observed at the surface along the southern portion of the LVF, where it seems to correlate with Lichi Mélange (Fig. 1), a formation which has received various debated interpretations (Biq, 1971; Wang, 1976; Ernst, 1977; Page and Suppe, 1981; Lin and Chen, 1986; Huang and Yin, 1990; Huang et al., 1992; Reed et al., 1992; Chang et al., 2000, 2001; Malavieille et al., 2002; Huang et al., 2006a, 2008; Chang et al., 2009).

The objective of this study is to investigate the potential factors that favor aseismic slip on the LVF based on structural and micro-structural analysis of the various formations along the LVF and of rocks from the fault zone. The study is based on field investigations and analysis of samples collected at the outcrops and from drill cores (Chen, 2009; Mu et al., 2011). Hereafter, we 
first describe the different stratigraphic units that compose the Longitudinal Valley area and discuss the nature and origin of the Lichi Mélange. We next discuss its correlation with the creeping section of the LVF, and we investigate the potential deformation mechanisms which could explain shallow creep on the LVF, based on structural and microstructural observations.

\section{Stratigraphic and tectonic setting of the Coastal Range}

The Coastal Range consists of the Luzon arc volcanic basement and forearc basins, which were accreted to the passive Chinese continental margin during the arc-continent collision, about 7 millions years ago (Teng and Wang, 1981; Suppe, 1984; Liu et al., 2000; Huang et al., 2006a). We describe here the various rock formations outcropping in their area, their stratigrahic and structural relationships and their mineralogical constituents. This discussion is based on the information available from the literature and our own observations. The location of the sites where observations were carried out and samples collected are indicated in supplemental Fig. S2. We conducted two field surveys and collected samples (73 total) for chemical and micro-structural analysis (80 thin sections). We used BSE and SEM to indentify the microstrucrures and X-ray diffraction to characterize the mineralogy. Fig. 2 shows our revised version of the geological map and cross-sections of the area where most of the field work was focused in order to better constrain the nature and origin of the Lichi Mélange as well as its stratigraphic relationship to the other formations of the Coastal Range.

With regard to the stratigraphy, five rock units can be distinguished in the Coastal Range. The Tuluanshan arc formation and the Fanshuliao volcanoclastic deposits are pre-collision island-arc lithofacies, whereas the Paliwan lithic flysch, the Peinanshan and Wuho conglomerates (molasse), and the 
Lichi Mélange are later syn/post-collision lithofacies (Fig. 1c).

\subsection{The Tuluanshan arc formation}

Stratigraphic and geochemical studies have shown that the Coastal Range is composed of three accreted Miocene-Pliocene volcanic islands, from north to south: Yuehmei, Chimei and Chengkuang-ao (Huang et al., 2006a, 2008). The volcanic rocks of the Tuluanshan formation represent the former Luzon arc (Teng and Lo, 1985). They are distributed all along the Coastal Range (Fig. 1c) and usually form mountain ridges, covering an area over $1 / 3$ of the Coastal Range. The Tuluanshan formation is considered to be the oldest formation of the Coastal Range. Most of the radiometric dates fall in the range from 23 to $5 \mathrm{Ma}$ with some extending to late Oligocene (29 Ma) and early Pleistocene (1.5 Ma) (Ho, 1969; Juang and Bellon, 1984; Yang et al., 1988; Chen et al., 1990; Lo et al., 1994; Yang et al., 1995). Looking at the youngest deposits of the Tuluanshan Formation (andesitic breccia, agglomerate, and tuff), microfossils and radiometric datings highlight a southwards decrease in age of the different volcanic islands that composed the Tuluanshan formation (Chimei, 8 - 5 Ma; Chengkuangao 5.6 - 3.3, Ma) (Ho, 1969; Chi et al., 1981; Juang and Bellon, 1984; Yang et al., 1988; Chen et al., 1990; Lo et al., 1994). Since the arc-continent collision lead to the cessation of volcanism, the last volcanic activity represents the transition from the subduction to the collision stage. In addition, the age difference between the Kankgou Limestone $(5.2-5.1 \mathrm{Ma})$ on the igneous Chimei complex and the Tungho Limestone $(3.1-2.9 \mathrm{Ma})$ exposed on the Chengkuangao volcanic sequence (Fig. 1c) (Huang et al., 1995, 1988) is in good agreement with a southward propagation of the collision and the related westward thrusting and accretion of the Luzon Arc onto the Asian continent.

A combined geochronological, geochemical and geophysical study of the 


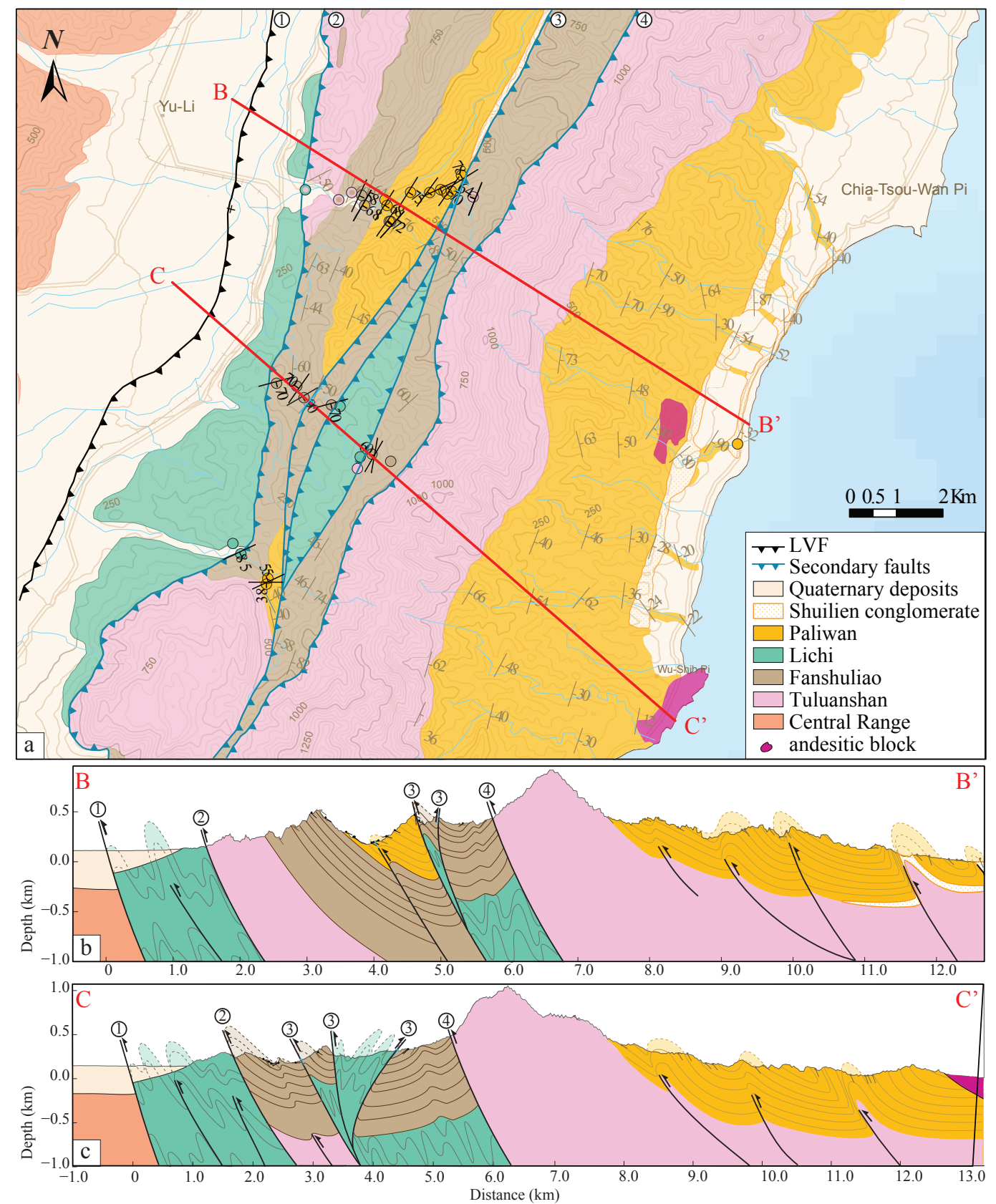

Figure 2: Geological map and cross-sections for the central part of the Longitudinal Valley, Taiwan. For location see Fig. 1. (a) Geological map is modified from Wang and Chen (1993) based on our field observations. Colored-circles show locations of samples. Field-measurements are displayed in black for the stratigraphy and in blue for the local faults. BB and CC show locations of cross-sections displayed in(b) and (c), respectively. Color coding for the different lithological formations of the Coastal Range are given in (a). Although we argue that the protolith of the Lichi Mélange is the Fanshuliao forearc deposits formation (see section 2.4), the two formations are assigned a different color coding for consistency with the Geological map of Wang and Chen (1993). 
Luzon arc has demonstrated that the Luzon arc presents a clear double arc structure related to the eastward shift in volcanism (5-4 Ma ago), most probably due to a change in the dip angle of the slab, which leads to the creation of a new volcanic chain (Yang et al., 1996). As the volcanism in the accreted islands had ceased before then, it is likely that the earlier volcanic centers were, in the early stage of the collision, closer to the trench than the current active volcanic islands. Therefore the three independent islands (Yuehmei, Chimei and Chengkuangao) were not necessarily aligned with the present Lutao and Lanshu Islands, south-east of Taiwan.

Volcanic features of the Tuluanshan formation indicate that most were produced by submarine eruptions and a small fraction by subaeraial extrusion (Teng and Lo, 1985). The following lithofacies have been documented, in the chronological order of their apparition: (i) lava, (ii) pyroclastics, and (iii) limestones (Teng and Lo, 1985; Teng et al., 1988; Chen, 1997a). A whole spectrum of rocks ranging from basalts, basaltic andesites and andesites can be found, among which andesites are the more voluminous (Teng and Lo, 1985). Phenocrysts are generally less than $50 \%$, of which plagioclase is usually the predominant phase. Hypersthene and other types of pyroxene are less than $5 \%$.

\subsection{Forearc and intra-arc basins: the Paliwan and the Fanshuliao formations}

Three Plio-Plesitocene remnant forearc basins (Shuilien, Loho, Taiyuan) and two intra-arc basins (Chingpu and Chengkung) have been recognized in the Coastal Range (Huang et al., 2006a, 2008). Submarine-fan channel deposits, together with paleocurrent measurements (Teng, 1982; Chen and Wang, 1988), indicate that the three forearc basins were originally one single basin before the Pliocene arc-continent collision (Huang et al., 1995). On the contrary, the Pliocene Chingpu and Pleistocene Chengkung intra-arc 
basins display no continuity in sediments deposits. They are believed to have developed as a pull apart basin, due to the oblique convergence, on the eastern part of the Neogene Chimei and Chengkuangao volcanic islands, respectively, prior to their accretion on the Coastal Range (Huang et al., 1995, 2006a).

Except limestones, most of the sedimentary deposits found in the forearc basin and intra-arc basins display primary sedimentary structures characteristic of turbidites, such as rhythmic alternations of thin persistent sandstone and shale beds, graded beds, sole marks and slump structures. Based on modal composition, Teng (1979) has distinguished three types of sedimentary rocks, reflecting the variation of sedimentary sources with time. Based on comparison with biostratigraphic studies of the area (Chang, 1967, 1968, 1969, 1975; Chi et al., 1981), Type I and II correspond to the so-called Fanshuliao formation, and Type III to the Paliwan formation (Fig. 1c).

\subsubsection{Fanshuliao formation}

Well exposed in the northern part of the Coastal Range, the Fanshuliao formation conformably overlies the Tuluanshan volcanics with a sometimes interfingering contact (Teng and Lo, 1985) (Fig. 2). The Fanshuliao formation is considered to consist of sediments which accumulated in the forearc basin between the rear of the accretionary prism and the Luzon arc islands (Huang et al., 2006b) (Fig. 6a). Biostratigraphic studies (Chang, 1967, 1968, 1969; Huang, 1969; Chang, 1975; Chi et al., 1981) show that the age of this formation roughly spans the latest Miocene to early Pliocene. Rythmic alternation of thin sandstone and mudstone beds (Fig. 3), together with common slump features (meter to hundred meters) are the dominant facies, but characteristic basal mudstone, which represents the draping mud over the volcanic arc in the early Pliocene, can locally be observed. Based on 


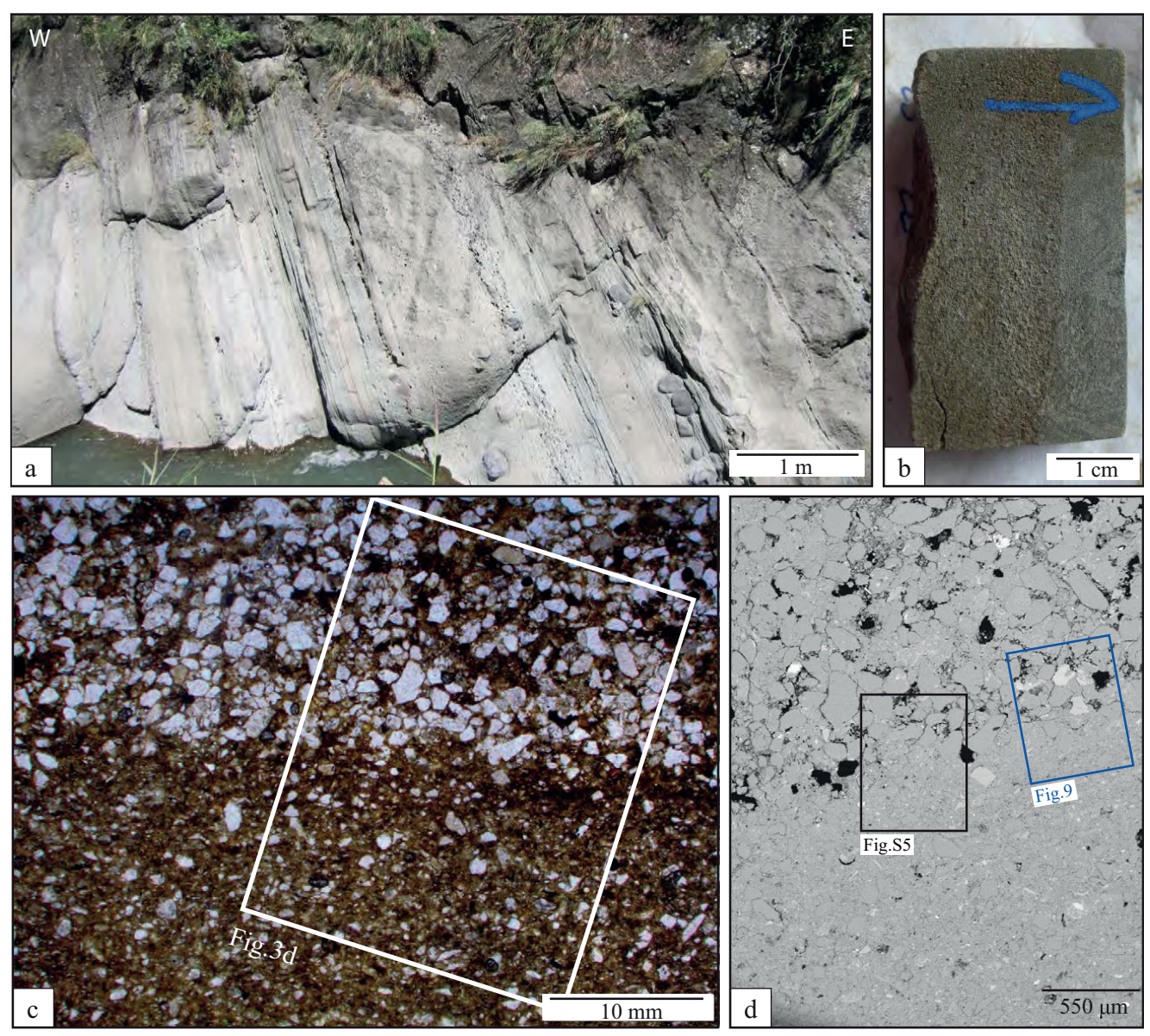

Figure 3: Fanshuliao formation. (a) Field view of a Fanshuliao outcrop along the LeHo River displaying a typical turbiditic Bouma sequence. (b) T12, a representative Fanshuliao sample collected in the field at longitude $121^{\circ} 22^{\prime} 05^{\prime \prime} \mathrm{E}$ and latitude $23^{\circ} 22^{\prime} 55^{\prime}$ N. See Fig. 1c for location. (c) Optical micrograph in plane polarized light. Sample exhibits a distinctive layering ( $\mathrm{s} 0)$ with variation in granulometry, characteristics of turbiditic deposits. The white rectangle displays the location of subfigure (d). (d) BSE image from the SEM. Black and blue boxes indicate location of pointshoot X-ray analysis with the SEM (Fig. S5 in supplements) and electron probe compositional maps in Fig. 9, respectively. 
probable source origin, the Fanshuliao formation can be further subdivided into two petrographic types, namely the calcarenaceous volcaniclastic sandstone (Type I) and the quartz-wacke sandstone (Type II) (Teng, 1979; Teng and Wang, 1981; Chen and Wang, 1988).

In terms of mineralogy content, Type I rocks are marked by a quasiabsence of quartz, a large proportion of volcanic origin feldspar plagioclase (10-40\%), the omnipresence of hornblende, some augite and opaques, occasional glauconite and chlorite, and few coalified wood fragments. The epiclastic content of volcanic origin is remarkable (over $50 \%$ of the total rock). A large quantity of carbonated bioclasts (20-70\% of the total rock) are also found, together with a micritic calcitic cement. Since the mineralogy contents is very similar to the Tuluanshan formation (Teng and Wang, 1981; Chen, 1997a), arc islands are likely the major source for these sedimentary rocks, transported by turbidity currents to the final depositional basin (Teng, 1979, 1980a). Moreover, the lack of terrigenous sediments combined with the abundance of fossil remains lead to the hypothesis of a primary inner, shallow-water shelf environment of deposition, far from the continent.

Unlike in rocks of Type I, quartz is an essential mineral of the quartzwacke sandstone (Type II), constituting 10 to $50 \%$ of the total rocks. Nevertheless, plagioclases still dominate, and K-feldpars also occur. With regard to accessory minerals, serpentine is more abundant than hornblende. Augite, chlorite, glauconite and micas can be also found, as well as zircon, tourmaline, garnet and monazite in the heavy fraction. Volcanic fragments are still the prevalent epiclasts, even though the relative quantity of lithic fragments is reduced. Slate fragments occasionally occur in Type II sandstone, and carbonated fossils are still present, but much less abundant than in Type I rocks. Carbonate cement forms an appreciable amount of these sandstones; 
nonetheless, the detrital clay matrix constitutes 4 to $47 \%$ of the total rock based on the Teng (1979) study. Pointshoot X-ray analysis with the SEM is presented in supplementary material (Fig. S5).

In the field, Type I and Type II rock units are interbedded, occur evenly and show similar textures. Therefore, they are hardly distinguishable without a petrographic analysis (Teng, 1979, 1980a). The main difference is in quartz and fossils content, as well as clay quantity. Consequently, Type II sandstone can be regarded as Type I rocks mixed, to a various extent, with a quartz and alkali feldspar-rich source, likely the non-metamorphic cover sequences of the proto-Taiwan island (Teng et al., 1988) (Fig. 6b).

\subsubsection{Paliwan formation}

Plio-Pleistocene in age, the Paliwan formation conformably overlies both the Fanshuliao and the Tuluanshan formations (Teng et al., 1988) (Fig. 1 and 2). Grayish in color, this formation includes the whole range of possible facies of deep-sea fan systems and corresponds to Type III sandstones, as described by Teng (1979). In terms of mineralogy content, quartz represents 7 to $32 \%$ of the total rock, feldspar is a minor accessory mineral, but serpentine is very common (Teng, 1979, 1980a). Detrital grains of pyroxenes are found as well, whereas amphibole is rare. The principal content of those rocks are epiclasts of different origin (14 to $90 \%$ of the total rock) with a relative abundant matrix, composed mainly of pelitic fragments and detrital clays in a smaller amount. Unlike in the Fanshuliao formation, bioclastic grains and calcareous cement are very limited in those rocks (Teng, 1979). The dominant type of lithic fragments is basic to ultrabasic igneous rocks, more or less serpentinized. Andesitic fragments are rarely present. The other epiclasts are slate and metasandstones (Teng, 1979, 1980a), with a progressive decrease through time in sedimentary lithic fragments and an 
increase first in low-grade and later in medium-grade methamorphic lithic fragments (Dorsey et al., 1988). The voluminous content of strained quartz, slate and metasandstone are undoubtedly derived from a low-grade metamorphic terrain, more likely the exposed Central Range (Teng, 1979; Dorsey et al., 1988). The source of the basic rocks is less certain. They might come from the erosion of ophiolite-bearing rock. Finally, the small amount of andesitic epiclasts tells us that the area of deposition was still not far from the arc.

\subsection{The Lichi Mélange}

The Lichi Mélange crops out on the western side of the Coastal Range (Fig. 1). Its stratigraphic thickness is quite variable and can reach up to $\sim 2$ km. Biostratigraphic studies (Chang, 1967; Chi et al., 1981; Chi, 1982; Barrier and Muller, 1984; Huang et al., 2008) show a consistent early Pliocene age, which restrains the time of deposition of the protolith to a narrow range (5.5 to $3.7 \mathrm{Ma}$ ). Therefore, the Lichi Mélange is coeval with the lower forearc basin sequence but older than the upper deposits of the Paliwan formation.

The Lichi Mélange is a characteristic block-in-matrix mélange with preferred foliation in a scaly argillaceous matrix with slickensided surfaces (Fig. 4a and b) and boudinage structures in the sandstone blocks (Chen, 1997b; Chang et al., 2000). Different sheared facies are observed in the Lichi Mélange: from weakly sheared/broken to highly sheared mélange facies (Chang et al., 2000, 2001; Huang et al., 2008). The weakly sheared, broken formation facies still preserves a distinct turbidite sedimentary structure with a basal layer primarily composed of quartz, like in the lower forearc sequences. However, slate chips, which are commonly found in the upper part of the forearc basin turbidite deposits (<3 Ma) (Teng, 1982), are generally absent in the Lichi Mélange (Huang et al., 2008). 


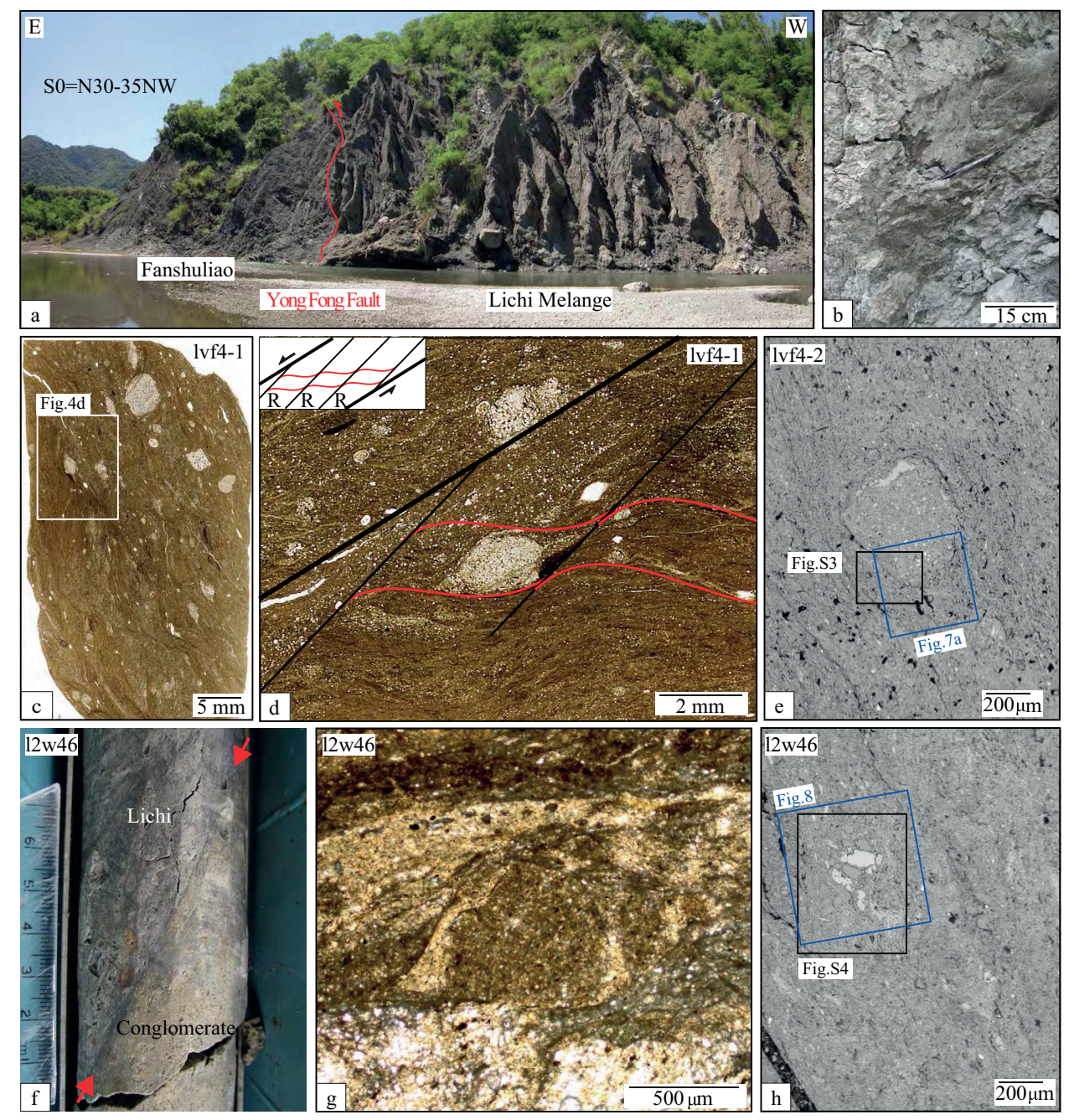

Figure 4: Lichi Mélange formation. (a) Contact between the Lichi Mélange and the Fanshuliao formation, near Fuli $\left(121^{\circ} 15^{\prime} 48^{\prime \prime} \mathrm{E}\right.$ and $\left.23^{\circ} 8^{\prime} 35^{\prime \prime} \mathrm{N}\right)$. The Lichi Mélange is highly erodible and exhibits characteristic v-shape erosion features in the field. (b) Outcrop of Lichi Mélange displaying the typical scaly argillaceous matrix with slickensided surfaces. (c) Thin section of lvf4 sample collected in the field $\left(121^{\circ} 14^{\prime} 32^{\prime \prime} \mathrm{E}\right.$ and $\left.23^{\circ} 9^{\prime} 56^{\prime \prime} \mathrm{N}\right)$ showing the block-in-matrix structure with penetrative foliation. See Fig. 1c for location. (d) Typical sigmoid-shaped microstructure with microlithons enmeshed in an clay-rich gouge and oriented along R-type Riedel shear fractures. (f) Borehole core Wan-2 (46.4 m depth along the core section) (Chen, 2009; Mu et al., 2011) displaying the tectonic contact (LVF) between the quaternary conglomerate and the Lichi Mélange. 12w46 samples the main fracture zone, highligthed with red arrows. (g) Optical micrograph in transmitted light showing a sigmoid-shaped clast of sanqstone. (e) and (h) BSE image from the SEM. Black rectangles indicate the location of the pointshoot X-ray analysis with the SEM (Fig. S3 and S4 in supplements). Blue boxes locate the electron probe compositional maps in Fig. 7 and 8 for (e) and (h), respectively. 
The exotic blocks inside the formation are of various size (millimeters to kilometers) and lithology (arc products, ophiolites, sedimentary rocks) (Fig 1). The volcanic products derived from the Luzon volcanic arc include andesite, volcanic breccias, tuffs and volcanoclastic turbidites. Pillow basalts and gabbro, sometimes serpentinized, composed the dismembered ophiolite suite. The larger block (several hundreds of meters) is known as the East Taiwan Ophiolite (ETO). Ophiolitic blocks appear to be restricted to the intensely sheared facies. They may represent the oceanic crust of either the South China Sea (Suppe et al., 1981; Jahn, 1986; Chung and Sun, 1992) or the Philippine Sea Plate beneath the Luzon forearc-arc (Juan et al., 1980; Malavieille et al., 2002). The source and emplacement mechanism of these basic products are still highly debated. Microfossil records from intercalated shale within the ophiolites gave an age of $15 \mathrm{Ma}$ (Huang et al., 1979), which is younger than, but close in age, to the youngest South China Sea crust (opening 32-17 Ma) (Briais et al., 1993). If the ophiolites came from the South China Sea, they would have been incorporated within the Lichi Mélange through the accretionary prism (Genti et al., 2012). Ophiolitic blocks inside the accretionary prism are observed in the Kenting mélange, i.e., west of the Hengchun Peninsula (southern extension of the Central Range), but not in the Central Range. Moreover, they differ from ETO in composition (Huang et al., 2008). The second potential source of these ophiolites is the basement of either the Luzon arc or the forearc basin. The microfossils are coeval with the age of the Luzon arc formation, which is not older than mid-Miocene (Huang et al., 2008). In that case, ophiolites would have been incorporated within the mélange at the same time as the arc products, during the shortening phase of the forearc basin (Huatung ridge equivalent). We favor this latter interpretation but further investigations are required to truly discrimi- 
nate between the two models. The sedimentary blocks show two different facies. One consists of weakly lithified Pliocene turbidite with similar lithology, age and sedimentary turbidite structures as the forearc basin strata (Fanshuliao). The Lichi Mélange also includes meter to kilometer size angular blocks of well-lithified, whitish quartz-rich, feldspathic sandstones, which are late Miocene in age. They have only been observed in the intensely sheared facies of the Lichi Mélange and a zircon fission track study has shown that they are similar to the non-metamorphosed deep-sea fan sandstones of the upper accretionary prism in the Hengchun Peninsula (Huang et al., 1997, 2008). Therefore, those whitish blocks are believed to have been incorporated by eastward thrusting into the deformed forearc strata (Huang et al., 2008).

Clay mineral composition $(<2 \mu \mathrm{m})$ of the muddy matrix and the sedimentary blocks is similar in all samples, regardless of shearing intensity (Huang et al., 2008). They are characterized by illite, chlorite, mixed-layer clay minerals (mica/smectite) and kaolinite (Lin and Chen, 1986) (Fig. 5 and S3 and S4 in supplements). Pure smectite and serpentine are found as traces or are completely absent. Therefore, the Lichi Mélange must have two sources: one continental with slightly metamorphosed sediments from the exhumed accretionary prism to provide illite and chlorite, and one volcanic to provide the kaolinite. The clay mineral assemblage in the turbidites of the remnant forearc basin is very similar in composition except for the kaolinite, which is absent in the Fanshuliao formation (Lin and Chen, 1986). Huang et al. (2008) claimed that the occurrence of kaolinite shows the tectonic involvement (thrusting, fragmentation and mixing) of the volcanic basement beneath the forearc basin, during the formation of the Lichi Mélange, with incorporation of the kaolinite from the arc formation by fluid flow along the sheared plan or fractures. Therefore, kaolinite is absent in the forearc basin 


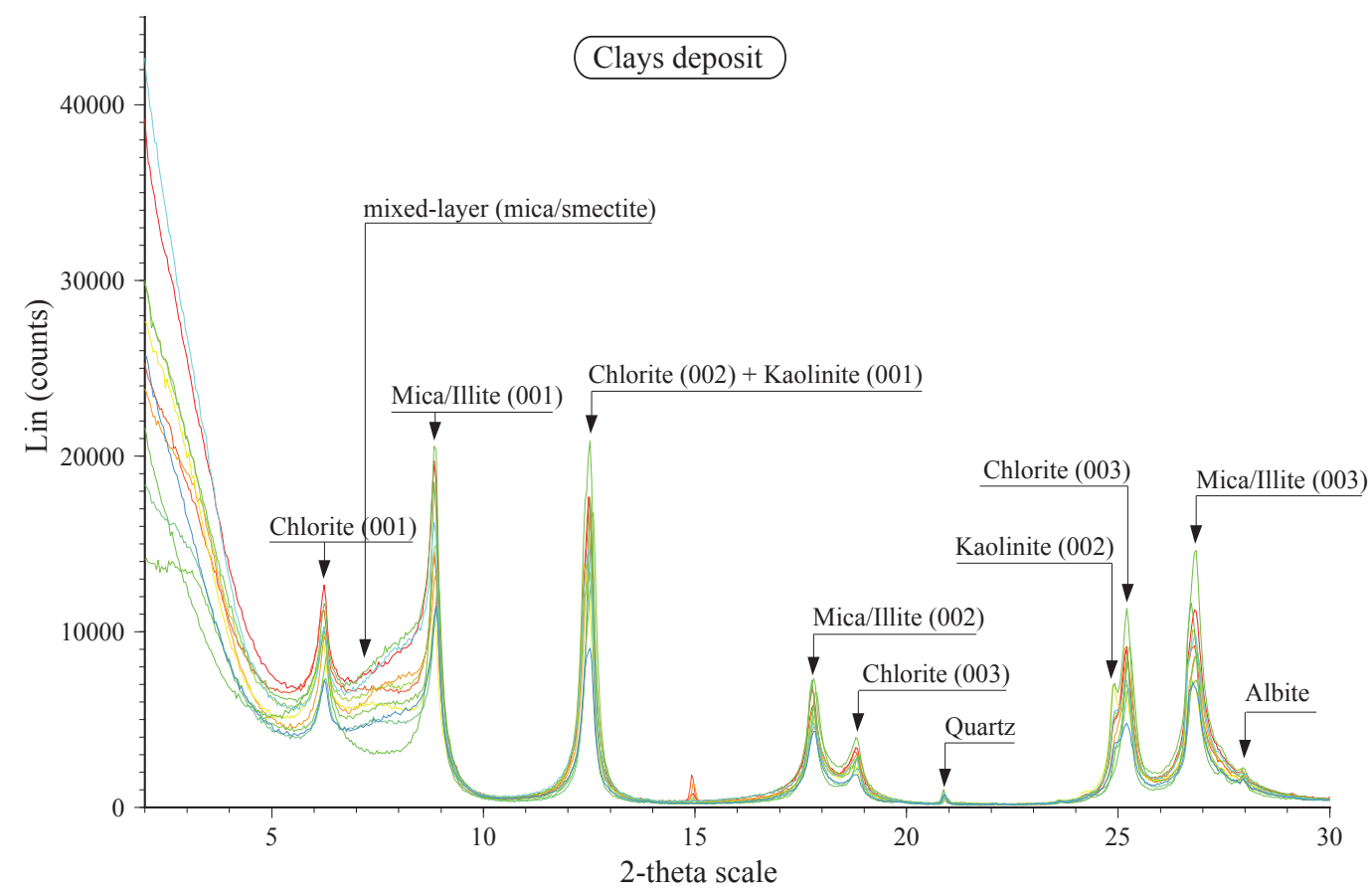

Figure 5: X-ray powder diffraction pattern of some oriented clay from Lichi Mélange matrix.

strata because they did not experience intense deformation.

\subsection{Stratigraphic relations between the Coastal Range formations}

Wherever overlain by the Fanshuliao deposits, the Tuluanshan formation is composed of debris-flow type breccias and turbidites. Moreover, although overlying the arc formation, the Fanshuliao deposits are contemporary to limestones and upper deposits of the Tuluanshan formation (Teng et al., 1988; Huang et al., 1988, 1995). This coevalness suggests that the Tuluanshan limestones and tuffs represent the shallow-water volcanic and fringing reefs environment, and the Fanshuliao turbidites and underlying Tuluanshan debris-flow deposits represent the deep-water deposits in the forearc basin (Teng and Wang, 1981; Teng et al., 1988; Teng and Lo, 1985; Chen, 1997a). The Paliwan sequences conformably overlie both the Fanshuliao and the 
Tuluanshan formations (Fig. 2 and 6). Where it is observed in direct contact with Tuluanshan deposits, the Paliwan formation generally consists of deep-marine mudstones and turbidites resting on either limestones or tuffs (Teng et al., 1988). The facies change associated with this contact is rather drastic and involves significant basin deepening (Teng et al., 1988; Huang et al., 1988, 1995). The contact between the Fanshuliao and the Paliwan formation varies with the facies character of the latter (Teng et al., 1988). While the boundary between the two sequences is a depositional contact in the southern Coastal Range, represented by one layer of pebbly sandstone (Chen and Wang, 1988), we clearly observe a sharp, erosional contact in the northern Coastal Range (Teng and Lo, 1985; Chen and Wang, 1988). Moreover, the formation exhibits overall a southward fining trend, with conglomerates dominating in the north and sandstones in the south (Teng, 1982; Teng et al., 1988). These observations lead to the hypothesis of a northern source for the sediments, likely the proto-island of Taiwan.

The Lichi Mélange is mostly in faulting contact with the coherent forearc basin strata (Fanshuliao, Paliwan) and the Tuluanshan arc formation (Hsu, 1956; Teng and Lo, 1985) (Fig. 1 and 4b). Nevertheless, depositional contact between the Lichi and Fanshuliao were reported (Page and Suppe, 1981; Barrier and Muller, 1984; Huang et al., 2008). The Lichi Mélange has been intensely studied, and several origins have been proposed. It was first interpreted as a subduction complex, developed in the former Manilla Trench during the subduction of the South China Sea oceanic crust (Biq, 1971). But this interpretation is in contradiction to the position of the Lichi Mélange, which lies east of the accretionary wedge instead of within the accretion prism (Huang and Yin, 1990; Huang et al., 1992; Reed et al., 1992; Malavieille et al., 2002; Huang et al., 2008). The Lichi Mélange was later interpreted 
as an olistostrome (Wang, 1976; Ernst, 1977; Page and Suppe, 1981; Lin and Chen, 1986) due to slumping into the western part of the forearc basin of the exposed accretionary prism (proto-Central Range). However, marine seismic investigations in the early 1990s, combined with previous biostratrigraphic studies, clays composition and lithology of the exotic blocks inside the mélange, questioned this model and led instead to the proposal of a tectonic collision origin, where the protolith of the mélange is the forearc basin, and the exotic blocks have been incorporated during the early stage of the collision (Chang et al., 2000, 2001, 2009; Huang et al., 2006a, 2008). Indeed, the marine seismic profile in the south of Taiwan shows synchronous deformation and sedimentation in the western part of the forearc basin: once the sediments are deposited in the Luzon trough, the sequence is deformed and then covered unconformably by the overlying sequence (Huang et al., 2008; Hirtzel et al., 2009). On the other hand, in the eastern part of the forearc basin, sedimentation is continuous regardless of active deformation in the west (Hirtzel et al., 2009). Near the southern tip of Taiwan, seismic profiles reveal the progressive closure of the forearc basin by arcward thrusting of the forearc basin strata (Reed et al., 1992; Malavieille et al., 2002; Huang et al., 2008; Hirtzel et al., 2009). The accumulation of deformation and shortening of the forearc basin would have led to the development of the Huatung Ridge (Huang et al., 2008; Hirtzel et al., 2009), which connects northward with the Lichi Mélange in the southern Coastal Range.

Finally, based on the petrographic features and stratigraphic relations described above, it is likely that the Tuluanshan and the Fanshuliao formations can be grouped as the pre-collision island-arc lithofacies whereas the Paliwan and the Lichi Mélange formation corresponds to the syn-post collision lithofacies. Consequently, the Paliwan formation should be considered as a 
flysch. The effect of this initial collision is well recorded by the deposition of voluminous coarse-grained continent-derived clastics of the Shuilien Conglomerate (Fig. 1) in the northern Coastal Range (Teng and Wang, 1981; Teng, 1982), which started at about 3.5 Ma (Teng, 1982).

\subsection{Tectonic scenario}

The mineralogical content and field observations of the stratigraphic relations between the Coastal Range sequences give us clues as to the environment of deposition and tectonic history of the Coastal Range, which allow us to precisely locate the formations with regard to the creeping zone, and to propose the following scenario (Fig. 6), which is quite similar to the scenario proposed by Malavieille and Trullenque (2009) based on sandbox experiment. Both models have similar implications for the origin of the Lichi Mélange. The main difference lies in the fact that Malavieille and Trullenque (2009) assume that a very large piece of forearc broke-off at the time of the collision and was subducted later on. However, the eastward shift in volcanism 5-4 Ma ago, which leads to the creation of a new volcanic chain (Yang et al., 1996), suggests a change in size over time of the forearc basin. Moreover, marine seismic profiles (Huang et al., 2008; Hirtzel et al., 2009; Eakin et al., 2014) and bathymetry show that the Huatung ridge (Fig. 1a) seems to develop from the backstop of the accretionary prism, not against the arc. This is in contradiction with sandbox experiments that demonstrate you should expect the development of a topographic ridge against the low dip backstop of the arc as the foreac sliver subduct in front of the volcanic edifice (Malavieille and Trullenque, 2009). We therefore favor the view that the forearc had actually been eroded during the subduction process prior to the collision.

\section{Intra-Oceanic Subduction}


(a) $12 \mathrm{Ma}$ : Intra-Oceanic Subduction Stage (or present south of $21^{\circ} \mathrm{N}$ )

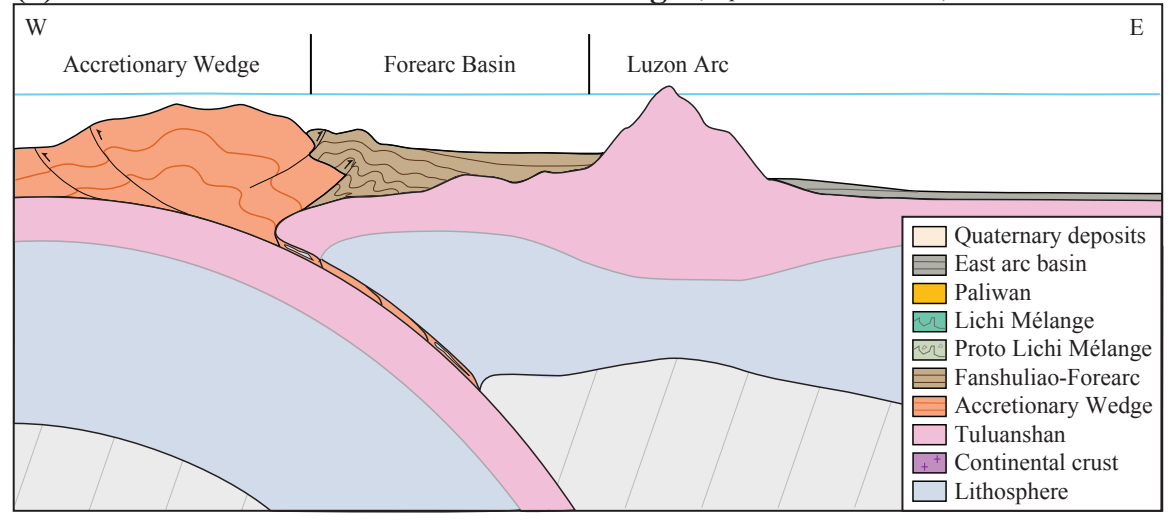

(b) $5 \mathrm{Ma}$ : Initial Arc-Continent Collision (or present $22^{\circ} 2^{\prime} \mathrm{N}$ )

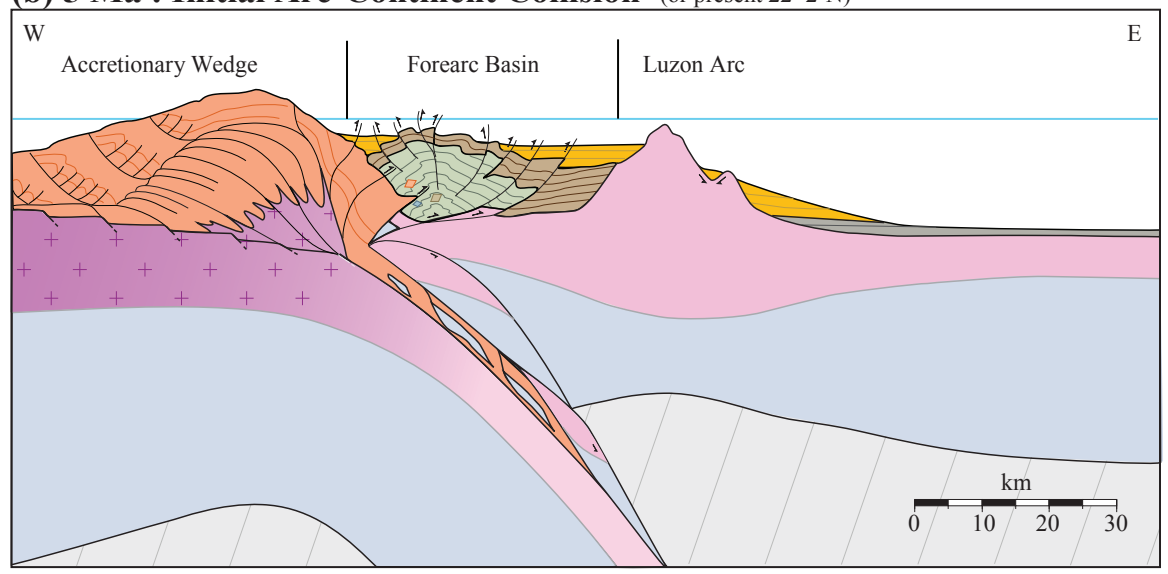

(c) Present : Advanced Arc-Continent Collision (or present north of $23^{\circ} \mathrm{N}$ )

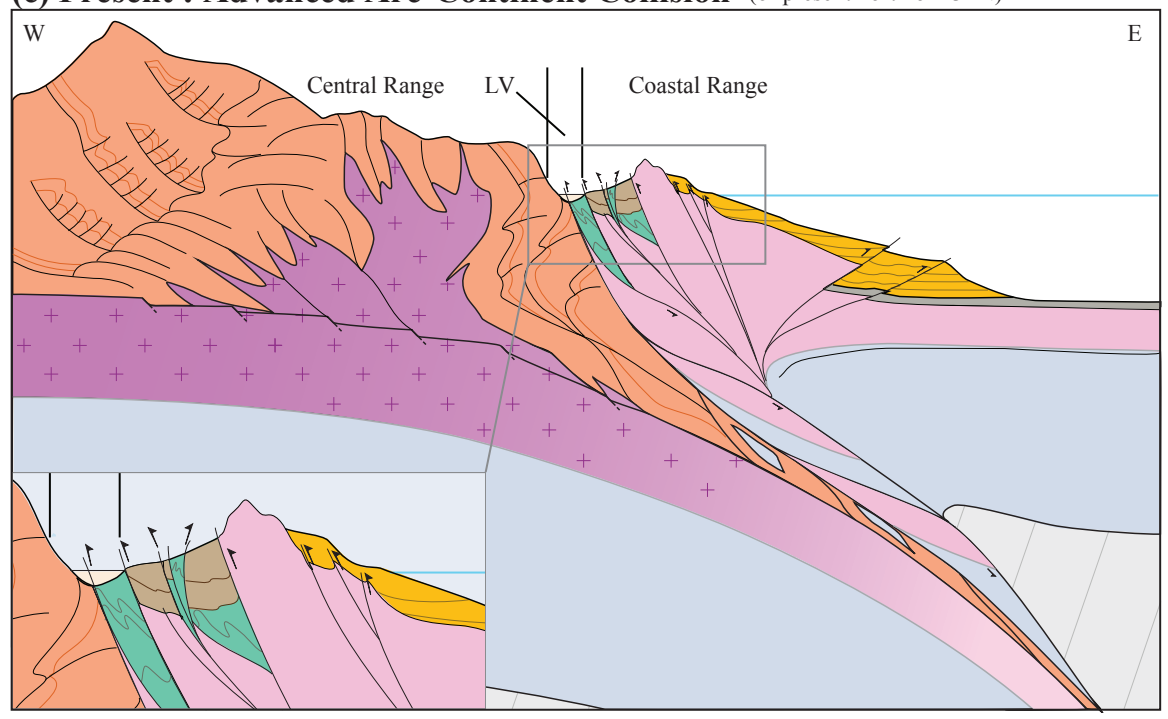

Figure 6: Tectonic sketching on the formation of the Coastal Range drawn based on field studies (Fig. 2), marine seismic profile (Huang et al., 2008; Hirtzel et al., 2009; Eakin et al., 2014) and sandbox experiments (Malavieille et al., 2002; Malavieille and Trullenque, 2009). (a) Tectonic setting at $12 \mathrm{Ma}$ (or present south of $21^{\circ} \mathrm{N}$ ): intra-oceanic subduction stage. (b) Tectonic setting at 5 Ma (or present $22^{\circ} 2^{\prime} \mathrm{N}$ ): initial arc-continent collision. (c) Current tectonic setting (or present north of $23^{\circ} \mathrm{N}$ ): advanced arc-continent collision. Note the vertical exageration of the topography and crustal section. 
Rifting within the Eurasian continent in the Oligocene ( $\sim 32 \mathrm{Ma})$ gave rise to the opening of the South China Sea until the Middle Miocene $(\sim 17$ Ma) (Briais et al., 1993). According to radiometric dating (Ho, 1969; Juang and Bellon, 1984; Yang et al., 1988; Chen et al., 1990; Lo et al., 1994), it was quickly followed by the eastward subduction of this basin, beneath the Philippine Sea Plate along the Manila Trench, leading to the creation of the volcanic Luzon arc. From Early Miocene (perhaps late Oligocene) to late Miocene, arc magmatism brought thick sequences of Tuluanshan volcanics and sediment offscraping, filling up the forearc basin (Fig. 6a). As observed now south of $21^{\circ} \mathrm{N}$ (profil GMGS973 in Huang et al., 2008), once the sediments are deposited in the Luzon trough (Fig. 1a), the sequence is synchronously deformed and then sometimes unconformably overlain by new sequences.

\section{Initial Arc-continent Collision}

The initiation of the arc-continent collision starts with the closure of the forearc basin, and consequently with the deformation of the forearc strata which leads to the formation of the proto-Lichi Mélange (Fig. 6b). The proto-Lici Mélange would be later called "Lichi Mélange" for strata displaying a more intense shearing. At the same time, as the subduction continues, more and more continental sediments are added in the accretionary prism, which is finally exhumed, providing a new source of deposits for the forearc basin. Cessation of volcanism is also a good marker of the earliest stages of the collision, which suggests a southward propagation : 8-5 Ma for Chimei based on nanofossils (Chi et al., 1981) and 3.3 for Chenkuangao based on fission track (Yang et al., 1988). Subsequently, fringing reefs start to grow on volcanic islands providing evidence of the termination of volcanism. The 
oldest Kankgou limestone on the Chimei volcanic island has been dated to 5.2 Ma, and Tungho Limestone (in the south, on the Chengkuangao complex) returned an age of 2.9 Ma (Huang et al., 1988, 1995). Based on those observations, it is reasonable to think that the initial arc-continent collision must have begun 7 to $8 \mathrm{Ma}$ ago and that it had already reached $23^{\circ} 5^{\prime} \mathrm{N}$ at 5.2 Ma (Suppe, 1984; Liu et al., 2000; Huang et al., 2006b). The equivalent state is located now at $22^{\circ} 2^{\prime} \mathrm{N}$, as observed in seismic (profile MW9006-31 in Huang et al., 2008). This southward propagation is consistent with the obliquity of the edge of the continental shelf of South China with respect to the subduction zone, which implies a southward migration rate of $90 \mathrm{~mm} / \mathrm{yr}$ based on Suppe (1984) or 60 mm/yr based on Byrne and Liu (2002). A study of the subsidence and uplift of the basins in the Coastal Range (Dorsey et al., 1988) also concluded a migration rate of about $60 \mathrm{~mm} / \mathrm{yr}$.

\section{Advanced Arc-Continent Collision}

The westward thrusting and accretion of the Luzon arc and forearc sequences onto the Asian continent, conjointly with the exhumation of metamorphic basement in the Central Range, mark the final stage of the arc-continent collision (Fig. 6c). This stage should be younger than the youngest strata found on the forearc basin sequences. Bio- and magnetostratigraphic studies (Chang, 1975; Chi et al., 1981; Horng and Shea, 1997; Lee et al., 1991) indicate that Coastal Range formations must have been accreted roughly 1.5 Ma ago in the north and 1.1 Ma in the south (Huang et al., 2006b).

\subsection{Origin of latitudinal variations in the occurrence of the Lichi Mélange}

The Lichi Mélange is thus interpreted as the result of the deformation of the forearc strata and basement in the early stage of the collision. One might then wonder why there is almost no occurrence of the Lichi Mélange in the 
northern half of the Coastal Range.

First, the indications that the volcanic activity within the Luzon arc shifted eastwards (Yang et al., 1996) question the past extend of the forearc basin compared to current setting, south of $21^{\circ} \mathrm{N}$. Indeed, in the early stage of the collision, the earlier volcanic centers were likely closer to the trench than the current active volcanic islands. Moreover, we should consider an increase over time of sediment supply in the foreac basin, with the exhumation of the accretionary prism and the continental basement. Consequently, if we assume that the protolith of the Lichi Mélange matrix are the forearc deposits, we should expect a northward reduction of the thickness of the collision Mélange.

Additionally, the northern termination of the Lichi Mélange outcrops correlates with a major tectonic feature of the Coastal Range, the Chimei Fault (Fig. 1b and c), which splits the Coastal Range into northern and southern blocks. It is a left-lateral reverse fault with NNE-SSW compression, which separates the Tuluanshan and the Paliwan formations (Fig. 1c) and which is ascribed a total offset of up to several kilometers (Chen et al., 1991; Kuo, 2013). Therefore, the Chimei fault, and a probable northward decrease in thickness of the Lichi Mélange formation, might explain the rather abrupt termination of the Lichi Mélange outcrops.

Finally, it is also possible that the highly erodible Lichi Mélange would have been eroded away thanks to the thrusting component and the high erosion rate estimated to be more than $10 \mathrm{~mm} / \mathrm{yr}$ in the Coastal Range (Dadson et al., 2003). Therefore, the few spotty outcrops of potentially Lichi Mélange reported to the north of the Chimei Fault (Fig. 1c) (Teng, 1980b) may well be the remnants of the Lichi formation, which was squeezed out upon land in the early stage of the collision. 


\section{Deformation mechanism in the Lichi Mélange}

\subsection{Spatial correlation of aseismic slip with the Lichi Mélange}

As mentioned in the introduction, the southern half of the LVF is clearly creeping at the surface. The lateral extent of the creeping segment is well revealed by the map of mean LOS velocity (in $\mathrm{cm} / \mathrm{yr}$ ) derived from the Permanent Scatter technique applied to PALSAR ALOS data acquired between 01/12/2007 and 09/07/2010 (Champenois et al., 2012; Thomas et al., 2014a) (Fig. 1b). This map shows a clear step in the LoS velocity field (positive toward the satellite) along the LVF, south of $23^{\circ} 30^{\prime} \mathrm{N}$. The discontinuity is clear evidence of aseismic slip near the surface for the southern portion of the LVF, and comparison with surface geology supports earlier inferences (Hsu et al., 2009a) that the Lichi Mélange would be responsible for promoting aseismic creep (Fig. 1). By contrast, no clear discontinuity (at the detection level of the technique, estimated to be $\sim 2 \mathrm{~mm} / \mathrm{yr}$ at the $67 \%$ confidence level) is observed along the northern half of the LVF, suggesting that the shallow portion of the fault has remained locked over the 2007-2010 period. The lack of aseismic slip correlates with the disappearance of the collision mélange since only isolated outcrops of the Lichi Mélange have been recognized north of the Chimei Fault (Teng, 1980b) (Fig. 1c). Therefore, in the particular case of the LVF, lithology seems to control the along strike variations of slip mode. We now examine the potential mechanisms which could explain enhanced aseismic creep where the fault is in contact with the Lichi Mélange. We examine in particular the difference of structure and mineralogical composition between the Lichi Mélange and the forearc formations. 


\subsection{Selection of field and core samples}

Two field surveys and one core sampling have been conducted to study the different units of the Coastal Range. A total of 59 samples from the Lichi Mélange, Fanshuliao, Tuluanshan and Pailwan outcrops were collected, and 63 thin sections were prepared and analyzed (see Fig. S2 in supplementary materials for location). We also sampled cores from shallow drillings, which were conducted near Chihshang (121 $\left.{ }^{\circ} 22 \mathrm{E}, 2^{\circ} 10 \mathrm{~N}\right)$ (Chen, 2009; Mu et al., 2011). We collected core samples from the fault zone, as expressed by the intense macroscopic fracturation and foliation: 14 samples from the Wanan sites (Wan-1 and Wan-2) were selected, and the analysis of 16 thin sections has been carried out. All petrographic sections were polished sections to allow both optical and electron microscopy. Samples containing Lichi Mélange were impregnated with clear epoxy resin before cutting. We first resorted to optical transmitted and polarized light microscopy to examine the mineralogy contents and microstructures. A total of 11 field samples were also selected to perform a clay mineral analysis of the Lichi Mélange (Fig. 5). Highresolution SEM combined with Energy-dispersive X-ray spectroscopy (EDS), as well as electron probe micro-analyzer were used for imaging the fault rock microstrures and determining the mineral phases of the Lichi samples from the fault zone (Fig. 9, 7, 8 and S3, S4, S5 in supplementary materials). The selection of samples was based on microscopy anaylsis.

Hereafter we describe four representative samples for describing the LVF: (1) lvf4, a Lichi Mélange sample collected in the field $\left(121^{\circ} 14^{\prime} 32^{\prime \prime} \mathrm{E}\right.$ and $23^{\circ} 9^{\prime} 56^{\prime \prime} \mathrm{N}$ ) on the LVF (Fig. 4c-d), (2) 11w29 a sample from the borehole core Wan-1 (Chen, 2009; Mu et al., 2011) at $29.1 \mathrm{~m}$ depth along the core section, which corresponds to the contact (LVF) between the quaternary deposits (conglomerate) and the collision melange, (3) $12 w 46$, a sample from 
the borehole core Wan-2 (Chen, 2009; Mu et al., 2011) at $46.4 \mathrm{~m}$ depth along the core section, displaying also the tectonic contact (LVF) between the quaternary conglomerate and the Lichi Mélange (Fig. 4f-h), and (4) T12, a typical Fanshuliao sample collected in the field at longitude $121^{\circ} 22^{\prime} 25^{\prime \prime} \mathrm{E}$ and latitude $23^{\circ} 22^{\prime} 55^{\prime \prime} \mathrm{N}$, as a protolith reference for the Lichi formation (Fig. 3). See Fig. 1c for the location of those for samples .

\subsection{Microstructural and analytical observations}

The fault gouge in the Lichi Mélange consists of altered, highly comminuted, scaly foliated rocks with slickensided surfaces and striations. All samples are pervasively sheared and display a characteristic anastomozing phyllosilicates foliation with sigmoidal microlithons and strain shadows (Fig. 4d and c) that define R-type Riedel shear surface (Rutter, 1986). They provide a clear indication of bulk ductile flow. Foliation is defined by millimetric to sub-millimetric alternation of clay and quartz-rich bands (Fig. 4a and b) that contain microstructural evidence of reworked cataclasites as well as mineralogic differentiation, which are likely related to pressure solution mass transfer (Fig. 7 and 8). Pyrite minerals in the gouge provide evidence for hydrothermal fluid flow (Fig. 8 and S3 in supplementary materials). Blocks in the matrix can be sub-millimetric to decimetric in size. In the thin sections we analysed they mostly consist of quartz-rich or calcite-rich lithic fragments with micro-fossils. Most remarkably, there are no veins in the gouge. By contrast, sandstone blocks in the foliated matrix are pervasively fractured with open fractures filled with calcite or breccias cemented by calcite (Chen, 1997b), which appear to have been injected, presumably under high fluid pressure.

The textural differences between the Fanshuliao formation (protolith equivalent) and the Lichi Mélange are emphasized by the electron probe micro- 
analyzer compositional maps presented in Fig. 7,8 and 9. The fault gouge, compared to Fanshuliao (Fig. 9) or the microlithons (Fig. 7), which represent an initial state of the Lichi Mélange, is dominated by the development of a very fine grain matrix and foliation seams with a depletion of $\mathrm{Si} \mathrm{Ca}$ and $\mathrm{Na}$ and a passive concentration of $\mathrm{K}, \mathrm{Al}, \mathrm{Fe} \mathrm{Mg}, \mathrm{S}$, Ti. This corresponds to the dissolution of soluble minerals, such as quartz, feldspars and calcite, and the passive concentration of phyllosilicates and titano-ferro oxides associated with a possible recrystallization of the phyllosilicates. Quartz, calcite and feldspar are, on the contrary, preserved inside the microlithons and in the strain shadows of those grains (Fig. 7 and 8).

\section{Discussion}

4.1. Deformation mechanisms of the Lichi Mélange and control on the aseismic behavior of the LVF

The primary fault zone processes observed in this study are the strong reduction of grain size and the pervasive foliation. Several processes might lead to grain-size reduction that include cataclasis, stress corrosion, dynamic recrystallization and neomineralization (Snoke et al., 1998). The Lichi Mélange samples show evidence of cataclastic flow, which has been interpreted to be related to the early deformation of the foreac basin strata, based on the crosscutting relation with the foliation (Chen, 1997b) (see section 2.4). On the other hand, the development of a strong anastomosing foliation inside the Lichi Mélange, the presence of sigmoidal porphyroclasts and microlithons and the evidence of strain shadows (Fig. 4, 7 and 8) demonstrate the dominant role of pressure solution creep. Stress-driven dissolution is also strongly supported by the depletion in Ca-Na feldspar, quartz and calcite in the foliated matrix, whereas we observe an enrichment in phyllosilicates and oxydes 


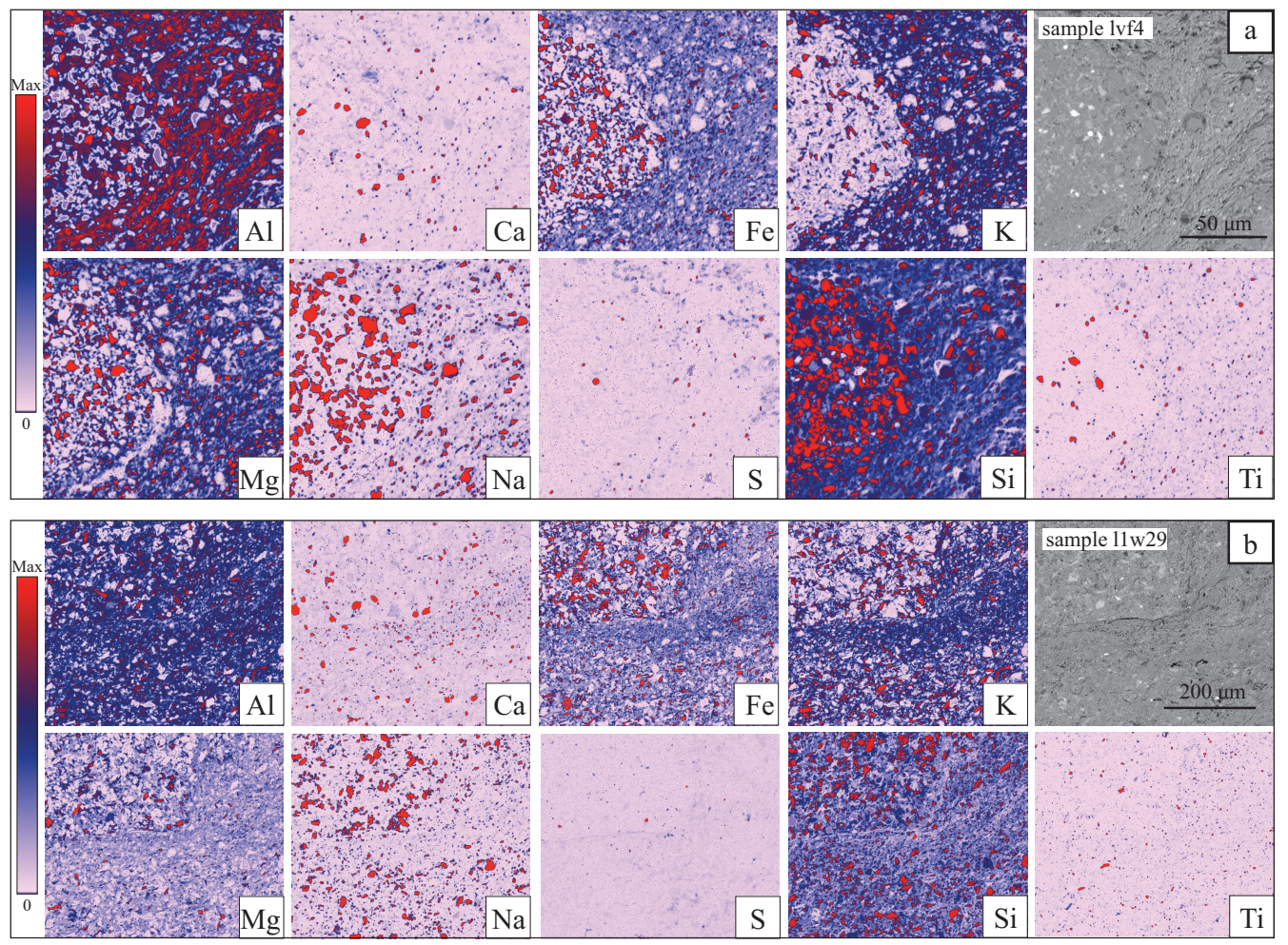

Figure 7: Electron probe micro-analyzer compositional maps of Lichi sample lvf4 (a) and 11w29 (b), displaying a microlithon enmeshed in foliated matrix. Sample lvf4 was collected in the field, inside the LVF fault gouge, and sample 11w29 has been collected on the borehole core Wan-1 (Chen, 2009; Mu et al., 2011) at 29.1 $\mathrm{m}$ depth along the core section, near the fault zone (Fig. 1c). For location of the analysis, see Fig. 4e. Red, blue and white colors indicates high, intermediate and missing contents respectively. The distribution of Aluminium indicates pervasive clay mineralization of the foliated matrix. The foliated gouge is also clearly depleted in $\mathrm{Si}, \mathrm{Ca}$ and $\mathrm{Na}$ and passively concentrated in $\mathrm{K}, \mathrm{Al}, \mathrm{Fe}, \mathrm{Mg}$, Ti, and $\mathrm{S}$ compared to the microlithon (initial state), showing a deficit in soluble minerals that is likely related to pressure-solution diffusive mass transfer. The top-right corner figure is the corresponding BSE image of the area. 

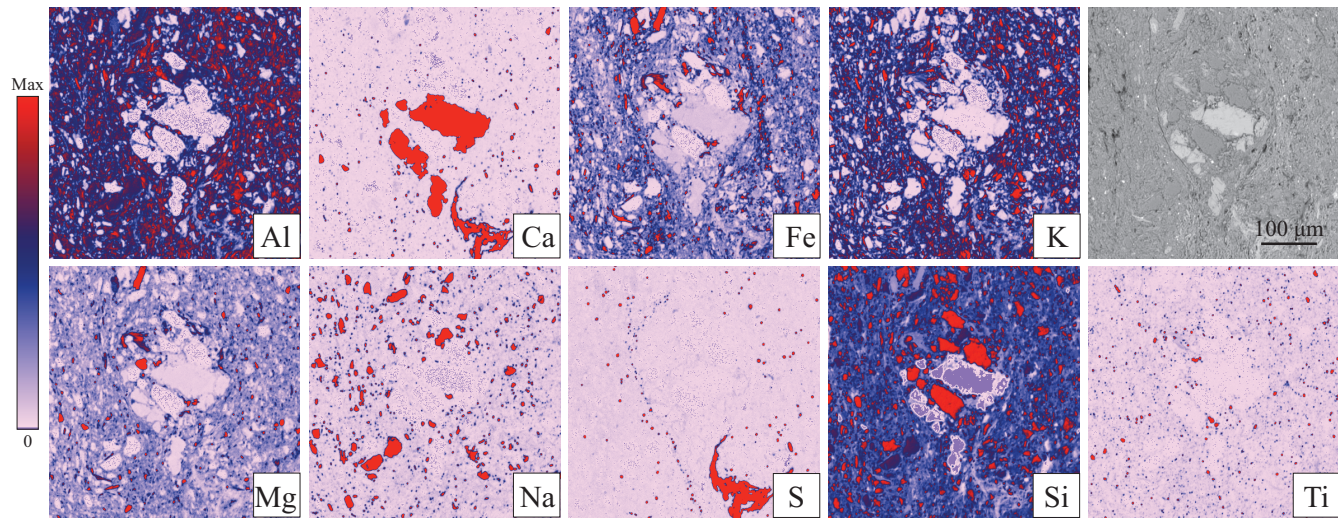

Figure 8: Electron probe micro-analyzer compositional maps of Lichi sample 12w46, displaying a sigmoidal microlithon embedded in foliated matrix. L2w46 was sampled on the borehole core Wan-2 at $46.4 \mathrm{~m}$ depth along the core section (Fig. 1c). For the location of the analysis, see Fig. 4h. Red, blue and white colors indicate high, intermediate and missing contents respectively. Distribution of Aluminium indicates pervasive clay mineralization of the foliated matrix. The foliated gouge is also clearly depleted in $\mathrm{Si}, \mathrm{Ca}$ and $\mathrm{Na}$, and passively concentrated in $\mathrm{K}, \mathrm{Al}$, $\mathrm{Fe}, \mathrm{Mg}$, Ti and $\mathrm{S}$ compared to the microlithon (initial state), showing a deficit in soluble minerals that is likely related to pressure-solution diffusive mass transfer. Evidence of pyrite masses in the gouge also favours the presence of hydrothermal fluid flow. The top-right corner figure is the corresponding BSE image of the area. 


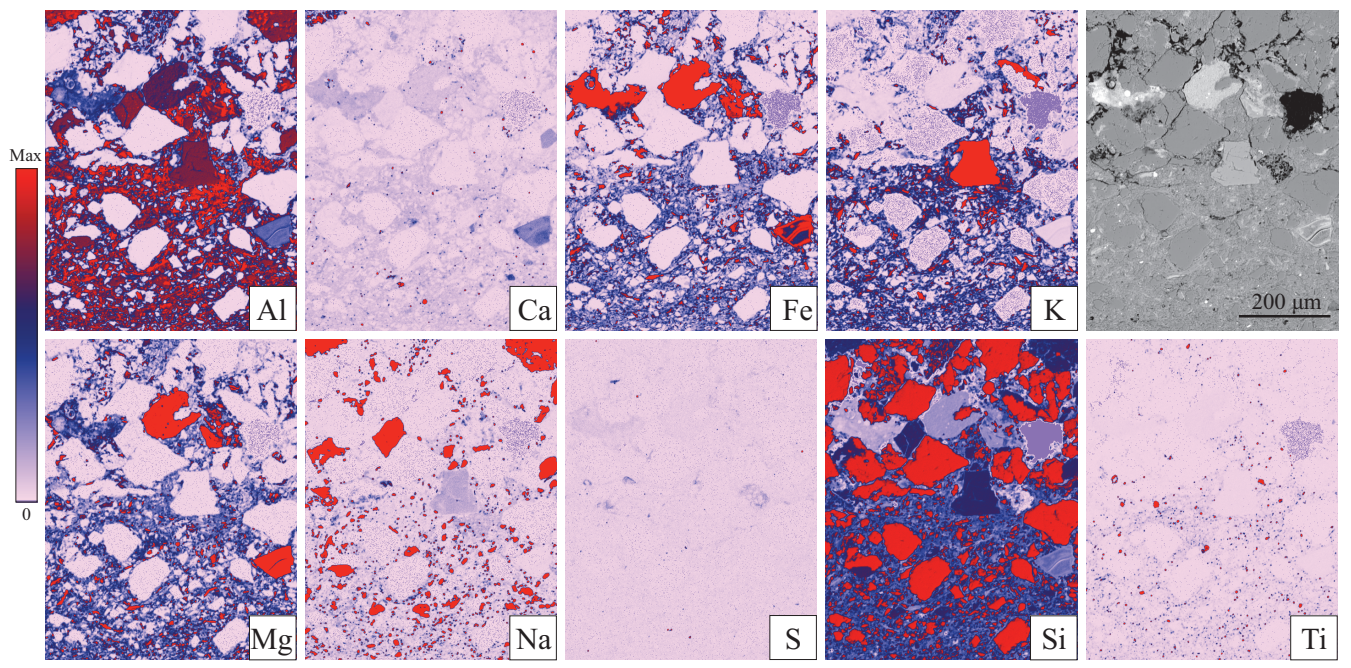

Figure 9: Electron probe micro-analyzer compositional maps of one typical foreacbasin formation sample (Fanshuliao) showing that no substantial differentiation is observed in the two sedimentary layers, which seems to display the same mineralogic contents (a slight increase in Ti may be inherited). The only difference stands in the grain size. For the location of the analysis, see Fig. 3d. The top-right corner figure is the corresponding BSE image of the area, and red, blue and white colors in the compositional map indicate high, intermediate and missing contents, respectively. 
(Fig. 7 and 8). There is no evidence of redeposition in veins nearby; however, soluble species may have been transported away from the zone of dissolution and such fluid flow may likely be the source of the hydro-fracturing observed in sandstone blocks (Chen, 1997b). It must be noted that the amount of redeposition, as pore or fracture sealing, is a key parameter for the creep rate because sealing process strengthen the rocks, since soluble minerals sealed together are more difficult to dissolve than when they are mixed with phyllosilicates (Gratier et al., 2013b).

The microstructural study of the fault zone samples shows that pressure solution has contributed to the deformation. However, pressure solution cleavage cannot accommodate very large strain values: a shortening value $\left(l_{1} / l_{0}\right)$ of 0.4 is about the maximum (Gratier et al., 2013a). Given the width of the shear zone and rapid slip rate across it, some other mechanisms of deformations are at play. Most probably, strain was accommodated by grain boundary sliding. Such a deformation mechanism can be operated by frictional sliding (with granular and/or cataclastic flows) or chemical processes, in which case pressure-solution creep controls the diffusion part of the sliding. In this instance, pressure-solution creep can accommodate large deformation (Gratier et al., 2013a). In addition to evidence of chemical processes, we can observe R-type Riedel slip surfaces in the clay-rich matrix that surround the microlithons (Fig. 4d). This, together with a strong reduction of grain size, suggest that cataclastic processes must contribute to the creeping process. Aseismic slip might also occur by a granular flow mechanism that involves frictional sliding of microlithons in a matrix of phyllosilicates.

\subsection{How pervasive is the aseismic deformation?}

The Lichi Mélange exhibits various degrees of strata fragmentation mixing and shearing: the weakly disturbed sequences still preserved distinct Bouma 
turbites sequences whereas higher grade of shearing display characteristics of block-in-matrix features with pervasive scaly foliation (Huang et al., 2008). Moreover, the formation is crosscut by secondary faults and numerous folds, that overall show no evidence of stretching parallel to their axis, which means they are likely synchronous with the ongoing shortening of the Coastal Range. However if field observations seem to favor a widely distributed deformation, the geodetic data underscore that between $23^{\circ} 09^{\prime} \mathrm{N}$ and $23^{\circ} 24^{\prime} \mathrm{N}$, creep is localized in a 100s of meters wide shear zone (Chang et al., 2009; Peyret et al., 2011; Champenois et al., 2012, and Fig. 1). Deformation is slightly more distributed (1 to $2 \mathrm{~km}$ wide) on the southermost section of the LVF, based on leveling profiles (Chen et al., 2012).

Among the samples we collected in the Lichi Mélange (in the field or from the drill cores), the strongest evidence of pressure solution creep were systematically observed in the samples that were located right near the tectonic contact (LVF) between the quaternary conglomerate and the lichi mélange (samples lvf4, 12w46 and 11w29). This support a strong localization of the aseismic deformation, like the geodetic data emphasize suggest.

\subsection{Influence of mineral frictional properties on fault slip mode}

The matrix of the Lichi Mélange is rich in illite, chlorite, mixed-layer clay minerals (mica/smectite), which are also common constituents of subduction mélanges. Illite has long been thought to be dominantly velocity-weakening and smectite velocity-strengthening. The illitization of subducted sediments (smectite transforms to illite when the temperature get higher than about $450^{\circ} \mathrm{C}$ ) was then considered to be the possible mechanism responsible for the updip limit of the seismogenic zone (Hyndman et al., 1997). Recent experimental work has shown that the illite clay gouge is actually velocitystrenghtening in the $0-250^{\circ} \mathrm{C}$ temperature range (Saffer and Marone, 2003; 
Saffer et al., 2012; den Hartog et al., 2012b,a). In fact, experimental studies show that, overall, unconsolidated and unlithified clay-rich gouges promote a velocity-strengthening behavior, and hence aseismic deformation, independently of their composition (in particular, the smectite/illite ratio) (Rutter and Maddock, 1992; Saffer and Marone, 2003; Ikari et al., 2009; Saffer et al., 2012). This result is consistent with the observation that the Lichi Mélange promotes aseismic slip at shallow depth on the LVF.

However, most intriguingly, there is no key mineralogical difference between the matrix of the Lichi Mélange along the creeping segment in the south and the forearc formations along the locked segment in the north. They only differ in the presence of kaolinite (see subsection 2.3), which displays both velocity-strengthening and velocity-weakening behavior at a low slip rate $(11 \mu \mathrm{m} / \mathrm{s})$, relatively low normal stress $(\sigma=20-50 \mathrm{MPa})$, and a high frictional strength $\left(f_{o}=0.6\right)$ (Ikari et al., 2011a). In agreement with previous mineralogic studies (Lin and Chen, 1986) we did not find evidence for talc, serpentine or saponite (a form of smectite), which have been advocated to account for the aseismic creep on the San Andreas fault (e.g, Solum et al., 2006; Morrow et al., 2007; Moore and Rymer, 2007; Lockner et al., 2011; Carpenter et al., 2011). Therefore, it seems unlikely that the inherent frictional properties of the fault zone mineral constituents can explain why aseismic creep is favored at shallow depth on the southern segment of the LVF.

Nevertheless, the development of the foliation itself, as a microstructural weakening mechanism, could have substantially altered the mechanical properties of the Lichi Mélange compared to its undeformed protolith. The development of the foliation indeed favors low friction minerals, which, even though they might represent a very low mass fraction of the constituents, 
can turn out to dominate the mechanical properties of a fault zone (Collettini et al., 2009; Niemeijer et al., 2010a; Ikari et al., 2011b). Besides, Ikari et al. (2011a) have found a systematic relationship between absolute frictional strength and the potential for unstable fault slip. Weak gouges, with coefficients of friction $\mu<0.5$, exhibit only stable sliding behavior, whereas strong gouges, with $\mu \geq 0.5$, exhibit both stable and unstable slip (Ikari et al., 2011a). Accordingly, even with similar mineralogic content, the well-foliated Lichi Mélange is more likely to display a velocity-strengthening behavior than the forearc basin strata that preserved the bedding structure.

\subsection{Can pressure solution creep explain the lithological control of aseismic slip on the LVF?}

The deformation observed in those fault zone rocks reflects the cumulative tectonic history since the onset of deformation of the Luzon forearc. The exhumed fault zone does not show much evidence for metamorphism, consistent with the low exhumation (less than 2km) (Shyu et al., 2006) and relative cold conditions (Temperature less than $450^{\circ} \mathrm{C}$ in the $0-30 \mathrm{~km}$ depth range) inferred from the thermokinematic modeling of Simoes et al. (2007). Note, however, that the estimated thermal structure is not well calibrated for the Coastal Range due to the lack of thermobarometric and thermochronological constraints in this area. However, it is likely that the deformation observed in the exhumed fault zone is representative of the ongoing deformation on the LVF at a relatively shallow depth (a few kilometers).

For pressure-solution creep to develop and accommodate large creep rate, specific conditions are required. Soluble minerals such a quartz, calcite or feldspar, which have been observed to be abundant in the Lichi Mélange, must be present and interact with a fluid phase. The PT conditions for pressure solution to exist are strongly dependent on the solubility of the minerals 
in solution and on the kinetic of the reactions. Evidence of pressure solution of calcite is seen all over the world as indented pebble in quaternary sediments, which were only buried at few hundred meters. Therefore this deformation mechanism can develop near the surface (Gratier et al., 2013a). Pressure solution of quartz requires however higher temperature, as both the solubility of quartz and the kinetic of dissolution are rather slow at low temperature. Evidence of dissolution of quartz have been described in sandstones basins by Bjorkum et al. (1998). Modeling the competition between mechanical and chemical compaction (pressure solution), these authors have shown that chemical compaction dominates above temperature of about $90^{\circ} \mathrm{C}$. In their model of pressure solution compaction, Renard et al. (1999) have also demonstrated that a significant decrease of porosity is inferred from 1.5 to $2 \mathrm{~km}$, accommodating compaction of about $20-100 \mathrm{~m} /$ Myr. Both studies show a close correspondence between measured porosities for a large variety of sandstone basins and the results of the modeling. Consequently, pressuresolution creep is efficient for calcite near the surface and become effective for quartz at about $2 \mathrm{~km}$ depth. Here we see on our samples the cumulative effect of theses processes since the Litchi Mélange, which is now at the surface, was dragged from depth along the thrust zone. Pressure-solution could contribute significantly to creep at shallow depth on the LVF if calcite is present, which is the case due to the relatively abundant microfossils content of the Lichi Mélange.

The rate of pressure solution creep is known to be inversely proportional to the cube of the grain size (Weyl, 1959; Rutter, 1976). Therefore, very fine grained material decreases the distance of diffusive mass transfer and consequently increases the efficiency of the deformation mechanism (Twiss and Moores, 1992; Gratier et al., 2011, 2013a). Finally, the enhancement of 
pressure-solution creep under the influence of phyllosilicates has been recognized (Weyl, 1959; Renard et al., 1997): clay minerals provide higher diffusivity in the contact layer and prevent the sealing of grains, which keep fast diffusive paths along solution seams (Niemeijer and Spiers, 2005; Gratier et al., 2011). Therefore, the Lichi Mélange, compared to others lithological formations in the Coastal Range, gathers the specific conditions for pressure solution creep to exist, to persist in time and to accommodate large strain rates. Relying on experiments and natural observations Gratier et al. (2011) show that pressure solution creep may accommodate strain rates as fast as $10^{-10} \mathrm{~s}^{-1}$ (at surface temperature with calcite and with quartz at few kilometers depth), which are compatible with strain rates associated with meter-width active fault with $\mathrm{cm} /$ year displacement rate as the LVF.

Pressure-solution creep has been shown to be a key factor in promoting aseismic deformation of synthetic fault gouge (Niemeijer et al., 2010b). This experimental study demonstrates that pressure-solution creep tends to inhibit the strain-weakening behavior associated with pure mechanical deformation of the fault gouge. We suspect that such a mechanism could explain the large fraction of aseismic slip on the LVF, including non-steady state postseismic deformation. Postseismic aseismic creep is highly non-linear in general, as was observed on the LVF, following the 2003 Chengkung Earthquake on the LVF (Lee et al., 2006; Hsu et al., 2009b; Chang et al., 2009; Thomas et al., 2014a). The abrupt acceleration of creep and the typical $1 / t$ decay of afterslip rate following that earthquake is consistent with the behavior predicted by velocity-strengthening frictional sliding (Marone et al., 1991; Perfettini and Avouac, 2004). However, it should be pointed out that velocity-strengthing friction is a phenomenological behavior that could result from a variety of different deformation mechanisms. Pressure-solution 
creep could actually be involved. Gratier et al. (2009) and Gratier (2011) have indeed demonstrated that micro-fractures development can drastically accelerate pressure solution creep rate: fracturing reduces the diffusive mass transfer distance, which is the rate-limiting effect. However, if the fractures are progressively sealed, this effect disappears and consequently reduces the displacement rate and shows exponential decrease (Gratier et al., 2009) or a power law decrease with an exponent of time of 0.35 (Gratier et al., 2013a). Such a mechanism would allow for reconciling the evidence for pressuresolution creep with the the acceleration of creep observed after the 2003 Chenkung earthquake and the later decay of afterslip rate. This could also explains at least part of the large fraction of aseismic slip observed at depth 80-90\% of the total slip between 0 and $26 \mathrm{~km}$ (Thomas et al., 2014a).

Note that evidence of slickensides in the Lichi suggest that frictional sliding must contribute to the creeping process. As the sliding occurs on relatively high friction minerals (see section 4.3) it must be associated with an increase in temperature. The partition between mass transfer through pressure-solution creep and frictional sliding could be inferred, in theory, by measuring the temperature inside the creeping zone.

\section{Conclusion}

Based on the previous kinematic study of the LVF (Thomas et al., 2014a) and the tectonic analysis of the Coastal Range rock formations, we conclude that there is a strong lithological control of the mode of slip on the LVF: the presence of the Lichi Mélange clearly promotes aseismic creep. This finding is consistent with experimental studies which have demonstrated the velocitystrengtehing behavior of clay-rich gouges at low $\left(T<250^{\circ} \mathrm{C}\right)$ temperatures (den Hartog et al., 2012a; Saffer et al., 2012). 
The lithological, meso- and microstructural evidence from the fault core samples suggest that it is likely that both frictional sliding (by cataclasis or granular flow) and pressure-solution creep concur to accommodate grain boundary sliding within the LVF gouge. A similar mode of deformation has been observed in experimental deformation of synthetic gouge (Niemeijer et al., 2010b) and advocated to accommodate the aseismic slip of the San Andreas Fault (Holdsworth et al., 2011; Hadizadeh et al., 2012). Presumably, in such a context of competing deformation mechanisms, the less energy-consuming process should dominate (Beeler et al., 1996). We argue that that pressure-solution creep is probably determining the creep rate, as in the experimental study, due to favorable conditions for pressure-solution creep inside the Lichi Mélange. As long as soluble minerals are present in the fault gouge, and those soluble species are transported away from the zone of dissolution, preventing restrengthening mechanisms such as cementation or fracture sealing, pressure-solution creep should be the dominating deformation mechanism. It has been proved to be an efficient mechanism to accommodate aseismic creep through the entire upper crust down to more than $10 \mathrm{~km}$ (Gratier et al., 2011). Episodic particle size reduction by cataclasis and alteration of feldspars to phyllosilicates are processes that would assist the pressure-solution creep mechanism and are likely to occur in the Lichi Mélange. The partition between dissolution and friction processes, which accommodate the sliding of the mineral elements, could be evaluated by measuring the temperature of the creeping zone, but this remains to be done.

This study suggests that aseismic creep is probably favored in the presence of any non-lithified subduction mélange, and that the internal structure of a fault gouge, namely the foliation, comminuted grain sizes, and the mix- 
ing of soluble and insoluble minerals, is more important in determining the mechanical properties of the fault zone than the mechanical properties of its mineral constituents, adding support to the view that fault zone fabric is essential in explaining fault mechanical properties (Collettini et al., 2009; Niemeijer et al., 2010a; Ikari et al., 2011b).

\section{acknowledgments}

This study was supported by the Gordon and Betty Moore Foundation through grant GBMF 423.01 to the Caltech Tectonics Observatory, and by the Keck Institute for Spaces Studies at Caltech. This is Tectonics Observatory contribution $\sharp 2$ ??. We thank the anonymous reviewer and Stéphane Dominguez for their insightful detailed comments that helped us improve the manuscript.

Angelier, J., Chu, H.T., Lee, J.C., 1997. Shear concentration in a collision zone: kinematics of the chihshang fault as revealed by outcrop-scale quantification of active faulting, longitudinal valley, eastern taiwan. Tectonophysics 274, 117-143.

Barbot, S., Lapusta, N., Avouac, J.P., 2012. Under the hood of the earthquake machine: Toward predictive modeling of the seismic cycle. Science 336, 707-710.

Barrier, E., Muller, C., 1984. New observations and discussion on the origin and age of the lichi mélange. Memoir of the Geological Society of China 6, 303-325.

Beeler, N.M., Tullis, T.E., Blanpied, M.L., Weeks, J.D., 1996. Frictional behavior of large displacement experimental faults. Journal of Geophysical Research-Solid Earth 101, 8697-8715. 
Biq, C., 1971. Comparison of mélange tectonics in taiwan and in some other mountain belts. Petroleum Geology of Taiwan 9, 79-106.

Bjorkum, P.A., Oelkers, E.H., Nadeau, P.H., Walderhaug, O., Murphy, W.M., 1998. Porosity prediction in quartzose sandstones as a function of time, temperature, depth, stylolite frequency, and hydrocarbon saturation. Aapg Bulletin-american Association of Petroleum Geologists 82, 637-648.

Briais, A., Patriat, P., Tapponnier, P., 1993. Updated interpretation of magnetic-anomalies and sea-floor spreading stages in the south china sea - implications for the tertiary tectonics of southeast-asia. Journal of Geophysical Research-Solid Earth 98, 6299-6328.

Byrne, T., Liu, C., 2002. Geology and geophysics of an arc-continent collision, Taiwan. Geological Society of America Special Paper. chapter Preface: Introduction to the geology and geophysics of Taiwan. pp. v-viii.

Carpenter, B.M., Marone, C., Saffer, D.M., 2011. Weakness of the san andreas fault revealed by samples from the active fault zone. Nature Geoscienceence 4, 251-254. URL: http://dx.doi .org/10.1038/ngeo1089.

Champenois, J., Fruneau, B., Pathier, E., Deffontaines, B., Lin, K.C., Hu, J.C., 2012. Monitoring of active tectonic deformations in the longitudinal valley (eastern taiwan) using persistent scatterer insar method with alos palsar data. Earth and Planetary Science Letters 337, 144-155.

Chang, C.P., Angelier, J., Huang, C.Y., 2000. Origin and evolution of a mélange: the active plate boundary and suture zone of the longitudinal valley, taiwan. Tectonophysics 325, 43-62. 
Chang, C.P., Angelier, J., Huang, C.Y., Liu, C.S., 2001. Structural evolution and significance of a mélange in a collision belt: the lichi mélange and the taiwan arc-continent collision. Geological Magazine 138, 633-651.

Chang, L., 1967. A biostratigraphic study of the tertiary in the coastal range, eastern taiwan, based on smaller foraminifera (i. southern part). Proceeding of the Geological Society of China 10, 64-76.

Chang, L.S., 1968. A biostratigraphic study of the tertiary in the coastal range, eastern taiwan, based on smaller foraminifera (ii. northern part). Proceeding of the Geological Society of China 11, 19-33.

Chang, L.S., 1969. A biostratigraphic study of the tertiary in the coastal range, eastern taiwan, based on smaller foraminifera (iii. midlle part). Proceeding of the Geological Society of China 12, 89-101.

Chang, L.S., 1975. Tertiary biostratigraphy of taiwan. Geology and Paleontology of SE Asia 15, 337-361.

Chang, S.H., Wang, W.H., Lee, J.C., 2009. Modelling temporal variation of surface creep on the chihshang fault in eastern taiwan with velocitystrengthening friction. Geophysical Journal International 176, 601-613.

Chen, C.H., Shieh, Y.N., Lee, T.P., Mertzman, S.A., 1990. Nd-sr-o isotopic evidence for source contamination and an unusual mantle component under luzon arc. Geochimica Et Cosmochimica Acta 54, 2473-2483.

Chen, H.Y., Lee, J.C., Tung, H., Yu, S.B., Hsu, Y.J., Lee, H., 2012. Determination of vertical velocity field of southernmost longitudinal valley in eastern taiwan: A joint analysis of leveling and gps measurements. Terrestrial Atmospheric and Oceanic Sciences 23, 355-376. 
Chen, W.S., 1997a. Lithofacies analyses of the arc-related sequence in coastal range, eastern taiwan. Journal of the Geological Society of China 40, 313338.

Chen, W.S., 1997b. Mesoscopic structures developed in the lichi mélange during the arc-continent collision in the taiwan region. Journal of the Geological Society of China 40, 415-434.

Chen, W.S., 2009. The fault slip long term velocity and recurrence period. Report of Central Geological Survey. Technical Report. Report of Central Geological Survey, pp. 31-40.

Chen, W.S., Huang, M.T., Liu, T.K., 1991. Neotectonic significance of the chimei fault in the coastal range, eastern taiwan. Proceeding of the Geological Society of China 34, 43-56.

Chen, W.S., Wang, Y., 1988. Development of deep-sea fan systems in coastal range basin, eastern taiwan. Acta Geologica Taiwanica 26, 37-56.

Cheng, L.W., Lee, J.C., Hu, J.C., Chen, H.Y., 2009. Coseismic and postseismic slip distribution of the $2003 \mathrm{mw}=6.5$ chengkung earthquake in eastern taiwan: Elastic modeling from inversion of gps data. Tectonophysics 466, $335-343$.

Chi, W., 1982. The calcareous nannofossils of the lichi mélange and the kenting mélange and their significance in the interpretation of plate tectonics of the taiwan region. Ti-Chih 4, 99-112.

Chi, W., Namson, J., Suppe, J., 1981. Stratigraphic record of plate interactions in the coastal range of eastern taiwan. Memoir of the Geological Society of China 4, 155-194. 
Chlieh, M., Avouac, J.P., Sieh, K., Natawidjaja, D.H., Galetzka, J., 2008. Heterogeneous coupling of the sumatran megathrust constrained by geodetic and paleogeodetic measurements. Journal of Geophysical ResearchSolid Earth 113, 31.

Chuang, R.Y., Miller, M.M., Chen, Y.G., Chen, H.Y., Shyu, J.B.H., Yu, S.B., Rubin, C.M., Sieh, K., Chung, L.H., 2012. Interseismic deformation and earthquake hazard along the southernmost longitudinal valley fault, eastern taiwan. Bulletin of the Seismological Society of America 102, 15691582.

Chung, L.H., Chen, Y.G., Wu, Y.M., Shyu, J.B.H., Kuo, Y.T., Lin, Y.N.N., 2008. Seismogenic faults along the major suture of the plate boundary deduced by dislocation modeling of coseismic displacements of the 1951 m7.3 hualien-taitung earthquake sequence in eastern taiwan. Earth and Planetary Science Letters 269, 415-425.

Chung, S.L., Sun, S.S., 1992. A new genetic model for the east taiwan ophiolite and its implications for drupal domains in the northern hemisphere. Earth and Planetary Science Letters 109, 133-145.

Collettini, C., Viti, C., Smith, S.A.F., Holdsworth, R.E., 2009. Development of interconnected talc networks and weakening of continental low-angle normal faults. Geology 37, 567-570.

Dadson, S.J., Hovius, N., Chen, H.G., Dade, W.B., Hsieh, M.L., Willett, S.D., Hu, J.C., Horng, M.J., Chen, M.C., Stark, C.P., Lague, D., Lin, J.C., 2003. Links between erosion, runoff variability and seismicity in the taiwan orogen. Nature 426, 648-651. 
Dorsey, R.J., Buchovecky, E.J., Lundberg, N., 1988. Clay mineralogy of pliocene-pleistocene mudstones, eastern taiwan - combined effects of burial diagenesis and provenance unroofing. Geology 16, 944-947.

Eakin, D.H., McIntosh, K.D., Van Avendonk, H.J.A., Lavier, L., Lester, R., Liu, C.S., Lee, C.S., 2014. Crustal-scale seismic profiles across the manila subduction zone: The transition from intraoceanic subduction to incipient collision. J. Geophys. Res. Solid Earth 119, 2013JB010395-- URL: http://dx.doi.org/10.1002/2013JB010395.

Ernst, W., 1977. Olistostromes and included ophiolite debris from the coastal range of eastern taiwan. Memoir of the Geological Society of China 2, 97114.

Genti, M., Malavieille, J., Molli, G., Dominguez, S., Taboada, A., VitaleBrovarone, A., 2012. Development of tectono-sedimentary mlanges in accretionary wedges: Insights from analog modeling, in: Geophysical Research Abstracts, EGU General Assembly.

Gratier, J.P., 2011. Fault permeability and strength evolution related to fracturing and healing episodic processes (years to millennia): The role of pressure solution. Oil \& Gas Science and Technology 66, 491 - 506.

Gratier, J.P., Dysthe, D.K., Renard, F., 2013a. The role of pressure solution creep in the ductility of the earth's upper crust. Advances In Geophysics, Vol 54 54, 47-179.

Gratier, J.P., Guiguet, R., Renard, F., Jenatton, L., Bernard, D., 2009. A pressure solution creep law for quartz from indentation experiments. Journal of Geophysical Research-Solid Earth 114, B03403. 
Gratier, J.P., Richard, J., Renard, F., Mittempergher, S., Doan, M.L., Di Toro, G., Hadizadeh, J., Boullier, A.M., 2011. Aseismic sliding of active faults by pressure solution creep: Evidence from the san andreas fault observatory at depth. Geology 39, 1131-1134.

Gratier, J.P., Thouvenot, F., Jenatton, L., Tourette, A., Doan, M.L., Renard, F., 2013b. Geological control of the partitioning between seismic and aseismic sliding behaviours in active faults: Evidence from the western, alps, france. Tectonophysics 600, 226-242. doi:10.1016/j.tecto.2013.02.013.

Hadizadeh, J., Mittempergher, S., Gratier, J.P., Renard, F., Di Toro, G., Richard, J., Babaie, H.A., 2012. A microstructural study of fault rocks from the safod: Implications for the deformation mechanisms and strength of the creeping segment of the san andreas fault. Journal of Structural Geology 42, 246-260.

Harris, R.A., Segall, P., 1987. Detection of a locked zone at depth on the parkfield, california, segment of the san andreas fault. Journal of Geophysical Research-Solid Earth and Planets 92, 7945-7962.

den Hartog, S.A.M., Niemeijer, A.R., Spiers, C.J., 2012a. New constraints on megathrust slip stability under subduction zone p-t conditions. Earth and Planetary Science Letters 353, 240-252.

den Hartog, S.A.M., Peach, C.J., de Winter, D.A.M., Spiers, C.J., Shimamoto, T., 2012b. Frictional properties of megathrust fault gouges at low sliding velocities: New data on effects of normal stress and temperature. Journal of Structural Geology 38, 156-171.

Hashimoto, C., Noda, A., Sagiya, T., Matsu'ura, M., 2009. Interplate seismo- 
genic zones along the kuril-japan trench inferred from gps data inversion. Nature Geoscienceence 2, 141-144.

Hirtzel, J., Chi, W.C., Reed, D., Chen, L.W., Liu, C.S., Lundberg, N., 2009. Destruction of luzon forearc basin from subduction to taiwan arc-continent collision. Tectonophysics 479, 43-51. doi:10.1016/j.tecto.2009.01.032.

Ho, C.S., 1969. Geological significance of k-ar ages of the chimei igneous complex of eastern taiwan. Bulletin of the Geological Survey of Taiwan $20,63-74$.

Holdsworth, R.E., van Diggelen, E.W.E., Spiers, C.J., de Bresser, J.H.P., Walker, R.J., Bowen, L., 2011. Fault rocks from the safod core samples: Implications for weakening at shallow depths along the san andreas fault, california. Journal of Structural Geology 33, 132-144.

Horng, C.S., Shea, K.S., 1997. Magnetobiostratigraphy of the mawu-chi section, southern coastal range, eastern taiwan. Journal of the Geological Society of China 40, 339-362.

Hsu, L., Burgmann, R., 2006. Surface creep along the longitudinal valley fault, taiwan from insar measurements. Geophysical Research Letters 33, 4 pp. -4 pp.

Hsu, T., 1956. Geology of the coastal range, eastern taiwan. Bulletin of the Geological Survey of Taiwan 25, 39-63.

Hsu, Y.J., Avouac, J.P., Yu, S.B., Chang, C.H., Wu, Y.M., Woessner, J., 2009a. Spatio-temporal slip, and stress level on the faults within the western foothills of taiwan: Implications for fault frictional properties. Pure and Applied Geophysics 166, 1853-1884. 
Hsu, Y.J., Yu, S.B., Chen, H.Y., 2009b. Coseismic and postseismic deformation associated with the 2003 chengkung, taiwan, earthquake. Geophysical Journal International 176, 420-430.

Huang, C.Y., Chien, C.W., Yao, B.C., Chang, C.P., 2008. The lichi mélange: A collision melange formation along early arcward backthrusts during forearc basin closure, taiwan arc-continent collision, in: Draut, A.E., Clift, P.D., Scholl, D.W. (Eds.), Formation and Applications of the Sedimentary Record in Arc Collision Zones. Geological Soc Amer Inc, Boulder. volume 436 of Geological Society of America Special Papers, pp. 127-154.

Huang, C.Y., Shyu, C.T., Lin, S.B., Lee, T.Q., Sheu, D.D., 1992. Marine geology in the arc continent collision zone off southeastern taiwan - implications for late neogene evolution of the coastal range. Marine Geology 107, 183-212.

Huang, C.Y., Wu, W.Y., Chang, C.P., Tsao, S., Yuan, P.B., Lin, C.W., Xia, K.Y., 1997. Tectonic evolution of accretionary prism in the arc-continent collision terrane of taiwan. Tectonophysics $281,31-51$.

Huang, C.Y., Yin, Y., 1990. Bathymetric ridges and troughs in the active arc-continent collision region off southeastern taiwan. Proceeding of the Geological Society of China 33, 351-372.

Huang, C.Y., Yuan, P.B., Song, S.R., Lin, C.W., Wang, C.S., Chen, M.T., Shyu, C.T., Karp, B., 1995. Tectonics of short-lived intraarc basins in the arc-continent collision terrane of the coastal range, eastern taiwan. Tectonics 14, 19-38.

Huang, C.Y., Yuan, P.B., Teng, L.S., 1988. Sedimentology and paleontology 
of the kangkou. limestone, northern coastal range, eastern taiwan. Acta Geologica Taiwanica 26, 133-160.

Huang, C.Y., Yuan, P.B., Tsao, S.J., 2006a. Temporal and spatial records of active arc-continent collision in taiwan: A synthesis. Geological Society of America bulletin 118, 274-288.

Huang, M.H., Hu, J.C., Hsieh, C.S., Ching, K.E., Rau, R.J., Pathier, E., Fruneau, B., Deffontaines, B., 2006b. A growing structure near the deformation front in sw taiwan as deduced from sar interferometry and geodetic observation. Geophysical Research Letters 33.

Huang, T.C., Chen, C.C., Chi, W.R., 1979. Calcareous nannofossils from the red shale of the ophiolite-mélange complex, eastern taiwan. Memoir of the Geological Society of China 3, 131-138.

Huang, T.Y., 1969. Some planktonic foraminifera from a borehole at shihshan, near taitung, taiwan. Proceeding of the Geological Society of China 12, 103-119.

Huang, W.J., Johnson, K.M., Fukuda, J., Yu, S.B., 2010. Insights into active tectonics of eastern taiwan from analyses of geodetic and geologic data. Journal of Geophysical Research-Solid Earth and Planets 115.

Hyndman, R.D., Yamano, M., Oleskevich, D.A., 1997. The seismogenic zone of subduction thrust faults. Island Arc 6, 244-260. URL: http://dx.doi.org/10.1111/j.1440-1738.1997.tb00175.x.

Ikari, M.J., Marone, C., Saffer, D.M., 2011a. On the relation between fault strength and frictional stability. Geology 39, 83-86. 
Ikari, M.J., Niemeijer, A.R., Marone, C., 2011b. The role of fault zone fabric and lithification state on frictional strength, constitutive behavior, and deformation microstructure. Journal of Geophysical Research-Solid Earth 116, B08404.

Ikari, M.J., Saffer, D.M., Marone, C., 2009. Frictional and hydrologic properties of clay-rich fault gouge. Journal of Geophysical Research-Solid Earth 114, B05409.

Jahn, B.M., 1986. Midocean ridge or marginal basin origin of the east taiwan ophiolite - chemical and isotopic evidence. Contributions to Mineralogy and Petrology 92, 194-206.

Juan, V., Lo, H., Chen, C.C., 1980. Genetic relationships and emplacement of the exotic basic rocks enclosed in the lichi mélange, east coastal range, taiwan. Proceeding of the Geological Society of China 23, 56-68.

Juang, W.S., Bellon, H., 1984. The potassium-argon dating of andesites from taiwan. Proceeding of the Geological Society of China 27, 86-100.

Kaneko, Y., Avouac, J.P., Lapusta, N., 2010. Towards inferring earthquake patterns from geodetic observations of interseismic coupling. Nature Geoscience advance online publication.

Kuo, S.T., 2013. Anatomy of folds in the damage zone of the chimei fault, eastern taiwan, in: EGU General Assembly.

Lee, J.C., Angelier, J., Chu, H.T., Hu, J.C., Jeng, F.S., 2001. Continuous monitoring of an active fault in a plate suture zone: a creepmeter study of the chihshang fault, eastern taiwan. Tectonophysics 333, 219-240. 
Lee, J.C., Angelier, J., Chu, H.T., Hu, J.C., Jeng, F.S., 2005. Monitoring active fault creep as a tool in seismic hazard mitigation. insights from creepmeter study at chihshang, taiwan. Comptes Rendus Geoscience 337, $1200-1207$.

Lee, J.C., Angelier, J., Chu, H.T., Hu, J.C., Jeng, F.S., Rau, R.J., 2003. Active fault creep variations at chihshang, taiwan, revealed by creep meter monitoring, 1998-2001. Journal of Geophysical Research-Solid Earth 108, 21.

Lee, J.C., Angelier, J., Chu, H.T., Yu, S.B., Hu, J.C., 1998. Plate-boundary strain partitioning along the sinistral collision suture of the philippine and eurasian plates: Analysis of geodetic data and geological observation in southeastern taiwan. Tectonics 17, 159-181.

Lee, J.C., Chu, H.T., Angelier, J., Hu, J.C., Chen, H.Y., Yu, S.B., 2006. Quantitative analysis of surface coseismic faulting and postseismic creep accompanying the $2003, \mathrm{~m}-\mathrm{w}=6.5$, chengkung earthquake in eastern taiwan. Journal of Geophysical Research-Solid Earth 111, 21.

Lee, J.C., Fu-Shu, J., Hao-Tsu, C., Angelier, J., Jyr-Ching, H., 2000. A rod-type creepmeter for measurement of displacement in active fault zone. Earth, Planets and Space 52, 321-328.

Lee, T.Q., Kissel, C., Barrier, E., Laj, C., Chi, W.R., 1991. Paleomagnetic evidence for a diachronic clockwise rotation of the coastal range, eastern taiwan. Earth and Planetary Science Letters 104, 245-257.

Lin, S.B., Chen, G.T., 1986. Clay minerals from the lichi mélange and its adjacent formations in the coastal range, eastern taiwan. Acta Geologica Taiwanica 24, 319-356. 
Liu, T.K., Chen, Y.G., Chen, W.S., Jiang, S.H., 2000. Rates of cooling and denudation of the early penglai orogeny, taiwan, as assessed by fission-track constraints. Tectonophysics 320, 69-82.

Lo, C.H., Onstott, T.C., Chen, C.H., Lee, T., 1994. An assessment of ar40/ar-39 dating for the whole-rock volcanic samples from the luzon arc near taiwan. Chemical Geology 114, 157-178.

Lockner, D.A., Morrow, C., Moore, D., Hickman, S., 2011. Low strength of deep san andreas fault gouge from safod core. Nature 472, 82-U107.

Loveless, J.P., Meade, B.J., 2011. Spatial correlation of interseismic coupling and coseismic rupture extent of the $2011 \mathrm{~m}-\mathrm{w}=9.0$ tohoku-oki earthquake. Geophysical Research Letters 38, L17306.

Malavieille, J., Lallemand, S.E., Dominguez, S., Deschamps, A., Lu, C.Y., Liu, C.S., Schnuerle, P., Angelier, J., Collot, J.Y., Deffontaines, B., Fournier, M., Hsu, S.K., Le Formal, J.P., Liu, S.Y., Sibuet, J.C., Thareau, N., Wang, F., 2002. Arc-continent collision in taiwan: New marine observations and tectonic evolution. Special Paper 358: Geology and Geophysics of an Arc-continent Collision, Taiwan 358, 187-211.

Malavieille, J., Trullenque, G., 2009. Consequences of continental subduction on forearc basin and accretionary wedge deformation in se taiwan: Insights from analogue modeling. Tectonophysics 466, 377-394.

Marone, C.J., Scholz, C.H., Bilham, R., 1991. On the mechanics of earthquake afterslip. Journal of Geophysical Research-Solid Earth and Planets $96,8441-8452$.

Moore, D.E., Rymer, M.J., 2007. Talc-bearing serpentinite and the creeping section of the san andreas fault. Nature 448, 795-797. 
Moreno, M., Rosenau, M., Oncken, O., 2010. 2010 maule earthquake slip correlates with pre-seismic locking of andean subduction zone. Nature 467, 198-U84.

Morrow, C., Solum, J., Tembe, S., Lockner, D., Wong, T..F., 2007. Using drill cutting separates to estimate the strength of narrow shear zones at safod. Geophysical Research Letters 34, L11301.

Mu, C.H., Angelier, J., Lee, J.C., Chu, H.T., Dong, J.J., 2011. Structure and holocene evolution of an active creeping thrust fault: The chihshang fault at chinyuan (taiwan). Journal of Structural Geology 33, 743-755.

Niemeijer, A., Marone, C., Elsworth, D., 2010a. Fabric induced weakness of tectonic faults. Geophysical Research Letters 37, L03304.

Niemeijer, A., Marone, C., Elsworth, D., 2010b. Frictional strength and strain weakening in simulated fault gouge: Competition between geometrical weakening and chemical strengthening. Journal of Geophysical Research-Solid Earth 115, B10207.

Niemeijer, A., Spiers, C.J., 2005. High-strain zones: Structure and physical properties. Geological Society of London Special Publication. volume 245. chapter Influence of phyllosilicates on fault strength in the brittle-ductile transition: Insight from rock analogue experiments. pp. 303-327.

Noda, H., Lapusta, N., 2010. Three-dimensional earthquake sequence simulations with evolving temperature and pore pressure due to shear heating: Effect of heterogeneous hydraulic diffusivity. Journal of Geophysical Research 115, B12314. 
Page, B.M., Suppe, J., 1981. The pliocene lichi mélange of taiwan; its platetectonic and olistostromal origin. American Journal of Science 281, 193227.

Perfettini, H., Avouac, J.P., Tavera, H., Kositsky, A., Nocquet, J.M., Bondoux, F., Chlieh, M., Sladen, A., Audin, L., Farber, D.L., Soler, P., 2010. Seismic and aseismic slip on the central peru megathrust. Nature 465, $78-81$.

Perfettini, H., Avouac, J.R., 2004. Stress transfer and strain rate variations during the seismic cycle. Journal of Geophysical Research 109, 8 pp.-8 pp.

Peyret, M., Dominguez, S., Cattin, R., Champenois, J., Leroy, M., Zajac, A., 2011. Present-day interseismic surface deformation along the longitudinal valley, eastern taiwan, from a ps-insar analysis of the ers satellite archives. Journal of Geophysical Research 116, B03402.

Reed, D.L., Lundberg, N., Liu, C.S., Luo, B., 1992. Structural relations along the margins of the offshore taiwan accretionary wedge: implications for accretion and crustal kinematics. Acta Geologica Taiwanica 30, 105122.

Renard, F., Ortoleva, P., Gratier, J.P., 1997. Pressure solution in sandstones: influence of clays and dependence on temperature and stress. Tectonophysics 280, 257-266.

Renard, F., Park, A., Ortoleva, P., Gratier, J.P., 1999. An integrated model for transitional pressure solution in sandstones. Tectonophysics 312, 97115. doi:10.1016/S0040-1951(99)00202-4.

Rutter, E., 1976. The kinetics of rock deformation by pressure solution. Philosophical Transactions of the Royal Society of London 283, 203-219. 
Rutter, E., Maddock, R., 1992. On the mechanical properties of synthetic kaolinite/quartz fault gouge. Terra Nova 4, 489-500. URL: http://dx.doi.org/10.1111/j.1365-3121.1992.tb00585.x.

Rutter, E.H., 1986. On the nomenclature of mode of failure transitions in rocks. Tectonophysics 122, 381-387.

Saffer, D.M., Lockner, D.A., McKiernan, A., 2012. Effects of smectite to illite transformation on the frictional strength and sliding stability of intact marine mudstones. Geophysical Research Letters 39, L11304.

Saffer, D.M., Marone, C., 2003. Comparison of smectite- and illite-rich gouge frictional properties: application to the updip limit of the seismogenic zone along subduction megathrusts. Earth and Planetary Sciences Letters. 215, 219-235.

Shyu, J.B.H., Chung, L.H., Chen, Y.G., Lee, J.C., Sieh, K., 2007. Reevaluation of the surface ruptures of the november 1951 earthquake series in eastern taiwan, and its neotectonic implications. Journal of Asian Earth Sciences 31, 317-331.

Shyu, J.B.H., Sieh, K., Avouac, J.P., Chen, W.S., Chen, Y.G., 2006. Millennial slip rate of the longitudinal valley fault from river terraces: Implications for convergence across the active suture of eastern taiwan. Journal of Geophysical Research-Solid Earth 111, B08403.

Simoes, M., Avouac, J.P., Beyssac, O., Goffe, B., Farley, K.A., Chen, Y.G., 2007. Mountain building in taiwan: A thermokinematic model. Journal of Geophysical Research-Solid Earth 112.

Snoke, A.W., Tullis, J., Todd, V.R., 1998. Fault-Related Rocks. Princeton University Press. 
Solum, J.G., Hickman, S.H., Lockner, D.A., Moore, D.E., van der Pluijm, B.A., Schleicher, A.M., Evans, J.P., 2006. Mineralogical characterization of protolith and fault rocks from the safod main hole. Geophysical Research Letters 33, L21314.

Suppe, J., 1984. Kinematics of arc-continent collision, flipping of subduction, and back-arc spreading near taiwan. Geological Society of China Memoir 6, 21-33.

Suppe, J., Liou, J.G., Ernst, W.G., 1981. Paleogeographic origins of the miocene east taiwan ophiolite. American Journal of Science 281, 228-246.

Teng, L.S., 1979. Petrographical study of the neogene sandstones of the coastal range, eastern taiwan (i. northern part). Acta Geologica Taiwanica 20, 129-155.

Teng, L.S., 1980a. Lithology and provenance of the fanshuliao formation, northern coastal. range, eastern taiwan. Proceeding of the Geological Society of China $23,118-129$.

Teng, L.S., 1980b. On the origin and tectonic significance of the lichi formation, northern coastal range, eastern taiwan. Ti-Chih 2, 51-62.

Teng, L.S., 1982. Stratigraphy and sedimentation of the shuilien conglomerate, northern coastal. range, eastern taiwan. Acta Geologica Taiwanica $21,201-220$.

Teng, L.S., Chen, W.S., Wang, Y., Song, S.R., Lo, H., 1988. Toward a comprehensive stratigraphic system of the coastal range, eastern taiwan. Acta Geologica Taiwanica 26, 19-35. 
Teng, L.S., Lo, H., 1985. Sedimentary sequences in the island arc settings of the coastal range, eastern taiwan. Acta Geologica Taiwanica 23, 77-98.

Teng, L.S., Wang, Y., 1981. Island arc system of the coastal range, eastern taiwan. Proceeding of the Geological Society of China 24, 99-112.

Thomas, M.Y., Avouac, J.P., Champenois, J., Lee, J.C., Kuo, L.C., 2014a. Spatiotemporal evolution of seismic and aseismic slip on the longitudinal valley fault, taiwan. Journal of Geophysical Research-solid Earth 119.

Thomas, M.Y., Lapusta, N., Noda, H., Avouac, J.P., 2014b. Quasidynamic versus fully-dynamic simulations of earthquakes and aseismic slip with and without enhanced coseismic weakening. Journal of Geophysical Research-solid Earth 119, 1986-2004. URL: http://dx.doi .org/10.1002/2013JB010615.

Twiss, R.J., Moores, E.M., 1992. Structural Geology. W. H. Freeman.

Wang, C.S., 1976. The lichi formation of the coastal range and arc-continent collision in eastern taiwan. Bulletin of the Geological Survey of Taiwan $25,73-86$.

Wang, Y., Chen, W., 1993. Geological map of eastern coastal range, 1:100,000. Central Geological Survey, MOEA, Taiwan .

Weyl, P.K., 1959. Pressure solution and the force of crystallization - a phenomenological theory. Journal of Geophysical Research 64, 2001-2025.

Wu, Y.M., Chen, Y.G., Shin, T.C., Kuochen, H., Hou, C.S., Hu, J.C., Chang, C.H., Wu, C.F., Teng, T.L., 2006. Coseismic versus interseismic ground deformations, fault rupture inversion and segmentation revealed by 2003 
mw 6.8 chengkung earthquake in eastern taiwan. Geophysical Research Letters 33, L02312.

Yang, T.F., Lee, T., Chen, C.H., Cheng, S.N., Knittel, U., Punongbayan, R.S., Rasdas, A.R., 1996. A double island arc between taiwan and luzon: Consequence of ridge subduction. Tectonophysics 258, 85-101.

Yang, T.F., Tien, J.L., xChen, J.L., Lee, T., Punongbayan, R.S., 1995. Fission-track dating of volcanics in the northern part of the taiwan-luzon arc: eruption ages ad evidence for crustal contamination. Journal of Southeast Asian Earth Sciences 11, 81-93.

Yang, T.Y., Liu, T.K., Chen, C.H., 1988. Thermal event records of the chimei igneous complex: Constraint on the ages of magma activities and the structural implication based on fission track dating. Acta Geologica Taiwanica 26, 237-246. 